\title{
DISKURSUS TERMINOLOGI MODEL, PENDEKATAN, STRATEGI, DAN METODE PEMBELAJARAN
}

\author{
Reksiana \\ Fakultas Tarbiyah Institut Ilmu Al-Qur'an Jakarta \\ reksiana@iiq.ac.id
}

\begin{abstract}
Abstrak
Dalam dunia pendidikan, beberapa istilah seperti strategi, pendekatan, model dan metode sering digunakan untuk menggambarkan situasi belajar-mengajar. Dan istilah-istilah tersebut sering tidak konsisten dan acap kali terjadi overlapping dalam penggunaannya. Untuk membedakan dan memperjelas perbedaan masing-masing istilah tersebut, perlu dikaji dan dibahas secara kontekstual dan komprehensif. Hal ini perlu dilakukan, guna tidak terjadi lagi kerancuan dan salah pemahaman makna dari beberapa istilah tersebut. Tulisan ini secara khusus akan mencoba menguraikan keempat istilah tersebut, karena keempat istilah tersebut paling banyak digunakan dan diacu oleh para praktisi di bidang pendidikan. Klarifikasi terhadap istilah-istilah tersebut akan membantu untuk menguraikan kerancuan pemahaman makna dalam dunia pendidikan dan dunia literasi.
\end{abstract}

Kata Kunci : Diskursus; Terminologi Mode; Pembelajaran

\begin{abstract}
In the world of education, several terms such as strategy, approach, model and method are often used to describe the teaching and learning situation. And these terms are often inconsistent and often overlapping occurs in their use. To differentiate and clarify each of these terms, it needs to be reviewed and discussed contextually and comprehensively. This needs to be done in order to avoid confusion and misunderstanding the meaning of each of these terms. This paper will specifically try to describe the four terms because the four terms are most widely used and referred to by practitioners in the field of education. Clarification of these terms will help to explain the ambiguity of understanding meaning in the world of education and literacy.
\end{abstract}

Key Word : Diskursus; Terminologi Mode; Pembelajaran 


\section{A. Pendahuluan}

Dalam proses pembelajaran, terdapat beberapa term atau istilah yang sering dipakai untuk menggambarkan keadaan kegiatan belajar mengajar di dalam kelas. Beberapa istilah ini adalah model, pendekatan, strategi, metode dan teknik pembelajaran, yang mana istilah-istilah ini sering menjadi perdebatan dan tidak konsisten, serta overlap dalam penggunaanya.

Menurut Ahwan Fanani dewasa ini berbagai cara berkembang dalam dunia pendidikan, terutama dalam mengembangkan desain pembelajaran. Dan, stilah-istilah dalam desain pembelajaran ini diberi label seperti metode, strategi, teknik, model dan juga pendekatan. Fanani menambahkan, bahwa label-label ini muncul dan mengidikasikan adanya perhatian besar bagi pengembangan dimensi cara dalam pembelajaran. Namun, dalam dunia pendidikan istilah-istilah ini tidak jarang menimbulkan kerancuan. ${ }^{1}$ Kerancuan beberapa istilah ini terjadi karena istilah-istilah ini mengacu pada dimensi yang sama. Dan jika ditelaah dari berbagai perspektif dan dan titik tekan akan bisa dibedakan. $^{2}$

Kerancuan ini pun menjadi semakin terlihat jelas. Hal ini disandarkan pada pernyataan yang menyamakan semua makna dari masing-masing istilah. Ramayulis dalam bukunya yang berjudul "Metodologi Pendidikan Agama Islam,". Jika dilihat dengan seksama di dalam buku tersebut, pada bagian daftar isi, Ramayulis mencoba mengklasifikasikan bagian metode dan model pembelajaran. Namun, setelah dilihat secara keseluruhan, pada bab model pembelajaran, Ramayulis menggunakan kata model dan metode secara bergantian, dalam artian menyamakan masing-masing makna istilah tersebut. ${ }^{3}$ Kemudian, dalam bab model pembelajaran, Ramayulis juga menggunakan Contextual Teaching and Learning (CTL) sebagai pendekatan, padahal

\footnotetext{
${ }^{1}$ Ahwan Fanani, "Mengurangi Kerancuan Istilah Strategi dan Metode Pembelajaran," Jurnal Pendidikan Islam 8, No. 2 (2014), lihat www.download.portalgaruda.org/article.php. (diakses pada tanggal $24 \mathrm{Mei}$ ).

${ }^{2}$ Ahwan Fanani, "Mengurangi Kerancuan Istilah Strategi dan Metode Pembelajaran," Jurnal Pendidikan Islam 8, No. 2 (2014), lihat www.download.portalgaruda.org/article.php. (diakses pada tanggal $24 \mathrm{Mei}$ ).

${ }^{3}$ Penulis membuka dan melihat satu per satu isi buku pada bab model dan metode, kata model dan metode digunakan secara bersamaan. Lihat Ramayulis, Metodologi Pendidikan Agama Islam (Jakarta: Kalam Mulia, 2013), xi dan hlm, 247-317.
} 


\section{|Rekssiana}

dalam bab judul Ramayulis sudah menggunakan kata model pembelajaran untuk kata CTL, dalam hal ini tanpa adanya klarifikasi lebih lanjut olehnya. ${ }^{4}$

Selanjutnya, pada bab model pembelajaran E-Learning, Ramayulis juga secara tidak konsisten menggunakan kata model dan strategi. Pasalnya, pada bab judul, Ramayulis menggunakan kata model, sedangkan pada bab isi menggunakan kata strategi. Terlihat dari penggunakan kata-kata yang tidak konsisten inilah menurut penulis adanya indikasi kerancuan penggunaan dan penempatan kata yang tidak tepat pada beberapa istilah tersebut. Karena, dalam beberapa buku seperti; "Model-model Pembelajaran Inovatif' karya Muhammad Fathurrohman, buku "Inovasi Pembelajaran Pendidikan Agama Islam" karangan Armai Arif, kemudian, dalam buku "Model-model Pembelajaran" karangan Rusman. Dalam buku-buku tersebut, secara jelas mereka memadankan kata Koopertif dan dan CTL pada model pembelajaran. ${ }^{5}$

Kerancuan istilah-istilah ini juga diperlihatkan oleh Aan Adrian dan koleganya Sudji Munadi yang memberikan lebel strategi, model dan metode pada Student Centered Learning (SCL) secara tidak konsisten. Lantaran, pada judul tulisan menggunakan kata strategi, dan pada bab pembahasan menggunakan kata model, kemudian, pada bab akhir, hasil pembahasan mereka menggunakan kata metode. ${ }^{6}$ Kerancuan lain pun juga ditemukan dalam tulisan Yuli Agusti Rochman, yang juga menunjukkan adannya overlapping dalam penggunaan istilah strategi, model dan metode. Kerancuannya terdapat pada penggunaan kata strategi Discovery Learning yang diletakkan pada judul tulisan, kemudian pada bab pembahasan tentang

\footnotetext{
${ }^{4}$ Penulis membuka dan melihat satu per satu isi buku pada bab model dan metode, kata model dan metode digunakan secara bersamaan. Lihat Ramayulis, Metodologi Pendidikan Agama Islam (Jakarta: Kalam Mulia, 2013), xi dan hlm, 237.

${ }^{5}$ Lihat Rusman, Model-model Pembelajaran: Mengembangkan Pfofesionalisme Guru (Jakarta: PT Raja Grafindo Persada, 2016), 131. Lihat Armai Arif, Inovasi Pembelajaran PAI, (Jakarta: UIN Press), 107, lihat juga Muhammad Fathurroman, Model-model Pembelajaran Inovatif (Jogjakarta: Ar-Ruzz Media, 2015), 29.

${ }^{6}$ Aan Ardian dan Sudji Munadi, "Pengaruh Strategi Pembelajaran Student-Centered Learning dan Kemampuan Spasial Terhadap Kreativitas Mahasiswa," Jurnal Pendidikan Teknologi dan Kejuruan 22, No. 4 (2015).
} 
Discovery Learning mengunakan kata model dan metode secara bergantian atau tidak konsisten. ${ }^{7}$

Kerancuan juga kembali terlihat, dalam tulisan Aceng Jaelani. Dengan jelas, pada tulisannya terdapat bancuh tentang istilah model dan strategi. Pasalnya, pada bagian judul istilah Kooperatif Learning dipadankan dengan istilah model pembelajaran. Kemudian, pada bagian abstrak Aceng mengunakan kata strategi. Selanjutnya, pada bab pembahasan tentang kooperatif learning menggunkaan kata strategi dan model secara bergantian dan tidak konsisten. Melihat hal ini, tentunya akan membuat orang-orang yang membaca akan menjadi salah pengertian dan bingung tentang pemaknaan katakata tersebut. Sementara, dalam Buku Penduan Kurikulum Pendidikan Tinggi sangat jelas Pembelajaran Kooperatif (cooperative learning) berpatutan dengan kata model bukan strategi. ${ }^{8}$

Melihat dari fakta-fakta ini, jelas sekali bahwa dalam menggunakan istilah-istilah seperti strategi, pendekatan, model dan metode masih adanya kerancuan dan salah pemahaman makna tentang masing-masing istilah tersebut. Untuk itu, penggunaan masing-masing istilah ini perlu dipahami dan dikaji secara kontekstual dan komprehensif. Hal ini perlu dilakukan guna mengurangi kerancuan dan salah penggunanaan istilahistilah tersebut dalam dunia pembelajaran dan dunia literasi. Pada bab selanjutnya akan didefinisikan dan dibahas secara mendalam dan komprehensif dari masing-masing istilah.

\section{B. Apa Itu Strategi Pembelajaran?}

Dalam dunia pendidikan, terdapat berbagai istilah-istilah yang acap kali ditemukan terkait dengan pengajaran di dalam kelas, dan salah satunya adalah strategi pembelajaran. Untuk mengetahui pengertian atau pemaknaan strategi pebelajaran ada baiknya dijelaskan terlebih dahulu asal usul dan makna leksikal dari strategi pembelajaran.

${ }^{7}$ Lihat Yuli Agusti Rochman, "Penerapan Discovery Learning sebagai Strategi Pembelajaran Mata Kuliah Perencanaan dan Pengendalian Produksi," Badan Pengembangan Akademik Universitas Islam Indonesia: Working Paper Series, (2015).

${ }^{8}$ Tim Kurikulum dan Pembelajaran Direktorat Pembelajaran dan Kemasiswaan, Buku Penduan Kurikulum Pendidikan Tinggi (Direktorat Jenderal Pendidikan Tinggi Kementerian Pendidikan dan Kebudayaan, 2014), 62. 


\section{|Reksiana}

Menurut Wina Sanjaya, istilah strategi pertama digunakan dalam dunia militer yang diartikan sebagai cara penggunaan seluruh kekuatan militer untuk memenangkan suatu peperangan. ${ }^{9}$ Kemudian, Sanjaya memberikan analogi lain untuk memberikan pengertian dan makna dari strategi ini tentang permainan dan pelatih sepak bola. Terkait hal ini, menurutnya, dalam permainan sepak bola, pelatih akan menentukan strategi yang akan dianggapkan tepat untuk memenangkan. Pelatih akan melihat semua potensi, teknik yang jitu dalam pertandingan. Ilustrasi yang digambarkan oleh Wina ini yang akhirnya menjadi suatu konklusi dalam memberikan pengertian tentang strategi, bahwa strategi digunakan untuk memperoleh kesuksesaan atau keberhasilan dalam mencapai tujuan. Selanjutnya, jika dikaitkan dengan dunia pendidikan, strategi dapat diartikan sebagai perencanaan yang berisi tantang rangkaian kegiatan tertentu, kemudian didesain untuk mencapai tujuan pembelajaran. ${ }^{10}$

Terkait pengertian strategi pembelajaran, Sri Anita mendefinisikan bahwa strategi juga dapat diartikan sebagai pola kegiatan pembelajaran yang dipilih dan digunakan guru secara kontekstual, sesuai dengan karakteristik siswa, kondisi sekolah, kemudian lingkungan sekitar, serta tujuan khusus pembelajaran yang dirumuskan. Penjelasan lebih lanjut, bahwa menurut Sri di dalam strategi terdiri dari metode dan teknik atau prosedur guna mencapai tujuan. Jelasnya, bahwa pemaknaan strategi pembelajaran lebih luas dari pada metode dan teknik pembelajaran metode dan teknik pembelajaran merupakan bagian dari strategi pembelajaran. ${ }^{11}$

Selanjutnya, Sri juga menguraikan, jika dalam strategi pembelajaran terdapat teori yang dijadikan landasan. Terkait hal ini, Sri mengangkat apa dikemukan oleh Crowl, Kaminsky dan Podell, dimana terdapat tiga pendekatan yang mendasari pengembangan strategi pembelajaran. Pertama, Advance Organizers dari Ausubel, yang merupakan pernyataan pengantar yang membantu siswa mempersiapkan kegiatan belajar baru dan menunjukkan hubungan antara apa yang akan dipelajari dengan

\footnotetext{
${ }^{9}$ Lihat Wina Sanjaya, Strategi Pembelajaran Berorientasi Standar Proses Pendidikan (Jakarta: Kencana, 2016), 125.

${ }^{10}$ Lihat Wina Sanjaya, Strategi Pembelajaran Berorientasi Standar Proses Pendidikan (Jakarta: Kencana, 2016), 126.

${ }^{11}$ Sri Anita W "Modul Strategi Pembelajaran," lihat epository.ut.ac.id/4401/2/PEFI4201-M1.pdf (diakses pada tanggal 20 Sepetember 2018).
} 
konsep atau ide yang lebih luas. Kedua, Discovery learning dari Bruner, yang menyarankan pembelajaran dimulai dari penyajian masalah dari guru untuk meningkatkan kemampuan siswa dalam menyelidiki dan menentukan pemecahannya. Ketiga, peristiwaperistiwa belajar dari Gagne. ${ }^{12}$

Untuk memperjelas pengertian strategi pembelajaran, Direktorat Tenaga Kependidikan Ditjen PMPTK memberikan pengertian terkait strategi pembelajaran. Di dalam Modul Strategi Pembelajaran, Direktorat Tenaga Kependidikan Ditjen PMPTK menyatakan, bahwa strategi dapat diartikan sebagai perencanaan yang berisi tentang rangkaian kegiatan yang didesain untuk mencapai tujuan pendidikan tertentu. Dan merupakan rencana tindakan (rangkaian kegiatan) termasuk penggunaan metode dan pemanfaatan berbagai sumber daya atau kekuatan dalam pembelajaran yang disusun untuk mencapai tujuan tertentu. Kemudian, terkait dengan strategi pembelajaran, terdapat beberapa hal yang perlu di perhatikan dalam proses pembelajaran. Ketiga hal tersebut yaitu (a) strategi pengorganisasian pembelajaran, (b) strategi penyampaian pembelajaran, dan (c) strategi pengelolaan pembelajaran. ${ }^{13}$

Lebih lanjut perihal strategi pembelajaran, Milan Rianto dkk turut menjabarkan bahwa di dalam strategi pembelajaran terdapat delapan ciri-ciri yang disandarkan pada peluang pada peserta didik untuk berperan aktif selama proses pembelajaran. Berikut ciri-ciri dari strategi pembalajaran yaitu: 1. Setiap tahapan kegiatan memungkinkan penggunaan berbagai macam sumber belajar, metode, dan media pembelajaran. 2. Selama proses pembelajaran mencerminkan kegiatan belajar yang beragam baik secara individu maupun kelompok. 3. Dalam kegiatan pembelajaran memungkinkan peserta didik belajar bekerja sama dan saling tukar-menukar pengalaman. Setiap tahapan kegiatan pembelajaran memberikan pengalaman belajar (learning experiences). 5. Setiap tahapan kegiatan permbelajaran memungkinkan bagi peserta didik untuk menumbuhkembangkan kemampuannya dalam berpikir secara kritis, kreatif, inovatif, dan produktif. 6. Setiap tahapan kegiatan pembelajaran memotivasi peserta didik untuk mengkaji lebih jauh bahan-bahan yang telah

\footnotetext{
${ }^{12}$ Sri Anita W "Modul Strategi Pembelajaran," lihat epository.ut.ac.id/4401/2/PEFI4201-M1.pdf (diakses pada tanggal 20 Sepetember 2018).

${ }^{13}$ Direktorat Tenaga Kependidikan Ditjen PMPTK, Modul Strategi Pembelajaran (Vesi Online), 3-5.
} 


\section{|Rekssiana}

dan sedang dipelajari 7. Dalam proses pembelajaran peserta didik memperoleh berbagai macam fasilitas belajar untuk melakukan kegiatan praktik dan/atau latihan.

Meninjau dari beberapa ciri-ciri yang telah dinyatakan tersebut, bahwa mengindikasikan bahwa strategi pembelajaran berupa prosedur atau pola umum dalam rangkian kegiatan pembelajaran dan memiliki karakteristik dan tahapan-tahapan tertentu. Bahkan, Yedi Purwanto menamakan ciri-ciri tersebut sebagai komponen-komponen pembelajaran, yang memiliki keterkaitan satu sama lain. Edi juga menambahkan keterangan bahwa terdapat sejumlah ayat Alquran yang berkaitan dengan masalah pendidikan, dapat disimpulkan petunjuk-petunjuk tentang komponen-komponen penting dalam pendidikan menurut Alquran. Dan di antaranya maslah tujuan pendidikan, peserta didik, pendidik, materi pendidikan, dan metode pendidikan. ${ }^{14}$ Berikut ayat Alquran yang terkait komponen-komponen dalam pembelajaran:

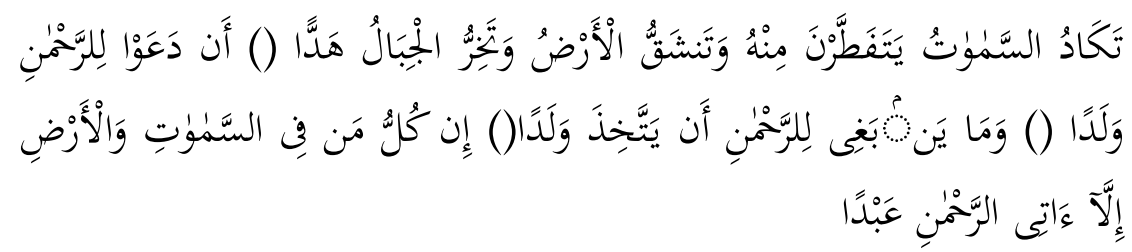

Artinya :"Hampir-hampir langit pecah Karena Ucapan itu, dan bumi belah, dan gunung-gunung runtuh. Karena mereka menda'wakan Allah yang Maha Pemurah mempunyai anak. Dan tidak layak bagi Tuhan yang Maha Pemurah mengambil (mempunyai) anak." (Q.S. Maryam [19]: 90-93).

Kemudian dalam surat lain juga diterangkan terkait hal ini, seperti dalam surat Ali-Imran yang berbunyi:

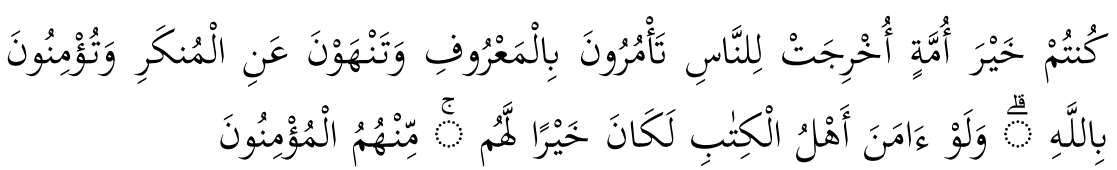

${ }^{14}$ Edi Puwanto, "Analisis terhadap Metode Pendidikan Menurut Alquran dalam Membentuk Karakter Bangsa," JUrnal Pendidikan Agama Islam: Ta'lim 13, No. 1 (2015). 
Artinya : "Kamu adalah umat yang terbaik yang dilahirkan untuk manusia, menyuruh kepada yang ma'ruf, dan mencegah dari yang munkar, dan beriman kepada Allah. Sekiranya ahli Kitab beriman, tentulah itu lebih baik bagi mereka, di antara mereka ada yang beriman, dan kebanyakan mereka adalah orang-orang yang fasik." (Q.S Ali-Imran [3]: 110).

Kemudian terdapat juga ayat yang memberi keterangan tentang peserta didik seperti dalam surat Q.S al-Baqarah yang berbunyi:

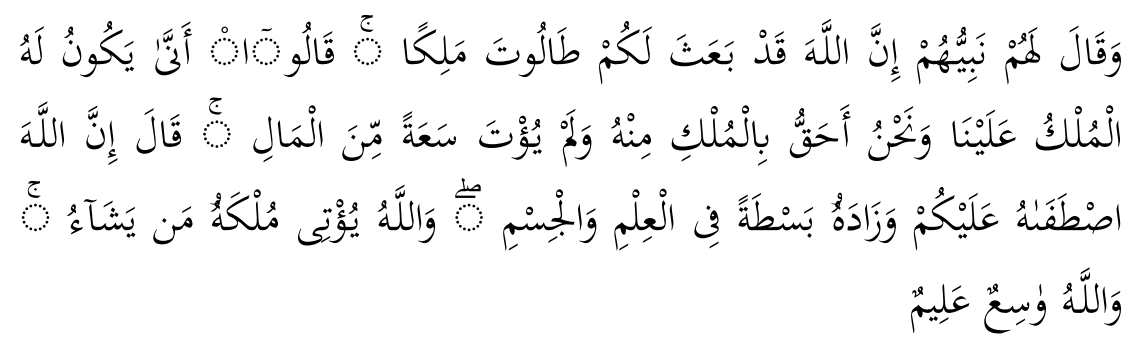

Artinya : "Nabi mereka mengatakan kepada mereka: "Sesungguhnya Allah Telah mengangkat Thalut menjadi rajamu." mereka menjawab: "Bagaimana Thalut memerintah kami, padahal kami lebih berhak mengendalikan pemerintahan daripadanya, sedang diapun tidak diberi kekayaan yang cukup banyak?" nabi (mereka) berkata: "Sesungguhnya Allah Telah memilih rajamu dan menganugerahinya ilmu yang luas dan tubuh yang perkasa." Allah memberikan pemerintahan kepada siapa yang dikehendaki-Nya. dan Allah Maha luas pemberianNya lagi Maha Mengetahui." Q.S al-Baqarah [2]: 247.

Bila diperhatikan, menurut Edi Purwanto dalam ayat tersebut mengisyarat tentang siapa peserta didik. Maka, menurutnya, dapat dipahami bahwa peserta didik adalah manusia yang beriman kepada-Nya. Dalam keterangannya, peserta didik terdiri dari manusia yang mempunyai dua dimensi utama dalam dirinya, yaitu jasmani dan rohani. Inilah yang kemudian akan dididik oleh para pendidik dengan mengacu pada ajaran-ajaran Ilahi dan sumber lainnya. ${ }^{15}$

${ }^{15}$ Edi Puwanto, "Analisis terhadap Metode Pendidikan Menurut Alquran dalam Membentuk Karakter Bangsa," JUrnal Pendidikan Agama Islam: Ta'lim 13, No. 1 (2015). 
Selain itu, agar memudahkan dalam mengenali apa itu strategi pembelajaran, dapat pula disertakan beberapa jenis strategi pembelajaran. Rowntree dalam Wina Sanjaya mengelompokkan ke dalam tiga strategi yaitu pertama, penyampaian-penemuan atau exspotion-discovery learning. Kedua, kelompok. Dan ketiga. individual atau group-individual learning.

Dalam strategi exspostion, bahan pelajaran disajikan kepada siswa dalam bentuk jadi dan siswa dituntut untuk menguasai bahan tersebut dengan pembelajaran langsung (direct instruction). Selanjutnya materi pelajaran disajikan begitu saja kepada siswa, dan siswa tidak dituntut untuk mengolahnya. Pada tahap selanjutnya, kewajiban siswa adalah menguasainya secara penuh. Dengan demikian, dalam strategi ekspositori guru berfungsi sebagai penyampai informasi. Berbeda dengan strategi discovery. Dalam strategi ini, bahan pelajaran dicari dan ditemukan sendiri oleh siswa melalui berbagai aktivitas, sehingga tugas guru lebih banyak sebagai fasilitator dan pembimbing bagi siswanya. Karena sifatnya yang demikian strategi ini sering juga dinamakan tidak langsung. ${ }^{16}$

Sementara dalam individual dilakukan oleh siswa secara mandiri. Kecepatan, kelambatan dan keberhasilan pembelajaran siswa sangat ditentukan oleh kemampuan individu siswa yang bersangkutan. ${ }^{17}$

Berbeda dengan strategi pembelajran individual, belajar kelompok dilakukan secara beregu. Kelompok siswa diajar oleh orang atau beberapa orang guru. Bentuk belajar kelompok itu bisa dalam pembelajaran kelompok besar atau pembelajaran klasikal atau bisa juga siswa belajar dalam kelompok-kelompok kecil semacam buzz group. $^{18}$

Kemudian, meninjau dari cara penyajian dan pengolahannya, strategi pembelajaran juga dapat dibedakan antara deduktif dan induktif, deduktif yaitu yang dilakukan dengan mempelajari konsep-konsep terlebih dahulu untuk kemudian dicari kesimpulan dan ilustrasi-ilusrasi; atau bahan pelajaran yang dipelajari dimulai dari hal-hal yang abstrak.

\footnotetext{
${ }^{16}$ Wina Sanjaya, Strategi Pembelajaran Berorientasi Standar Proses Pendidikan (Jakarta: Kencana, 2016), 125.

${ }^{17}$ Wina Sanjaya, Strategi Pembelajaran Berorientasi Standar Proses Pendidikan (Jakarta: Kencana, 2016), 125.

${ }^{18}$ Wina Sanjaya, Strategi Pembelajaran Berorientasi Standar Proses Pendidikan (Jakarta: Kencana, 2016), 125.
} 
Kemudian, secara perlahan-lahan menuju hal yang konkret. Srategi ini disebut juga dari umum ke khusus. Sebaliknya, dengan strategi induktif, pada strategi ini bahan yang dipelajari dimulai dari hal-hal yang konkret atau contoh-contoh yang kemudian secara perlahan siswa dihadapkan pada materi yang kompleks dan sukar. Strategi ini kerap dinamakan dari khusus ke umum. ${ }^{19}$

Terkait dengan pendekatan induksi adalah metode pemikiran yang bertolak dari kaidah (hal-hal atau peristiwa) khusus untuk menemukan hukum (kaidah) yang umum; penarikan kesimpulan berdasarkan keadaan yang khusus untuk diperlakukan secara umum penentuan kaidah umum berdasarkan kaidah khusus.

Setelah diberikan dan dipaparkan beberapa pengertian, dan jenisjenis strategi pembelajaran di atas, dapat ditarik suatu pengertian yang nyata, bahwa strategi pembelajaran ialah suatu komponen umum atau suatu set petunjuk umum mengajar yang di dalamnya terdapat landasan teori tertentu, dan terdapat prosedur yang akan digunakan bersama metode, serta bahan ajar untuk memperoleh hasil belajar tertentu.

\section{Apa Itu Pendekatan Pembelajaran?}

Term atau istilah lain yang juga harus diperhatikan dalam dunia pengajaran adalah pendekatan pembelajaran. Sebelum membahas definisi pendekatan lebih jauh. Terkait dengan pemaknaan apa itu pendekatan, maka menurut Nurjannah secara garis besar akan terbagi pada dibagi dua pemahaman makna. Pertama, pendekatan dimaknakan berarti memandang fenomena (budaya dan social). Pemaknaan tekait hal ini, bahwa pendekatan menjadi paradigma, sedangkan bila cara memandang atau menghampiri, pendekatan menjadi perspektif atau sudut pandang. Kedua, pendekatan berarti disiplin ilmu. Maka, terkait perihal ini, dapat disebut studi Islam dengan pendekatan sosiologis sama artinya dengan mengkaji Islam dengan menggunakan disiplin ilmu sosiologi. Konsekuensinya, pendekatan di sini menggunakan teori atau teori-teori dari disiplin ilmu yang dijadikan sebagai pendekatan.

Menurut T. Raka Joni dalam Sri Anita W. pendekatan (approach) ialah petunjuk atau cara umum dalam memandang

\footnotetext{
${ }^{19}$ Sri Anita W, "Modul Strategi Pembelajaran," lihat epository.ut.ac.id/4401/2/PEFI4201-M1.pdf (diakses pada tanggal 20 Sepetember 2018), 15.
} 


\section{|Rekssiana}

permasalahan atau objek kajian, sehingga berdampak. Menurutnya, pendekatan diibaratkan seorang yang memakai kacamata dengan warna tertentu di dalam memandang alam sekitar. Kacamata berwarna hijau akan menyebabkan lingkungan kelihatan kehijau-hijauan dan seterusnya. ${ }^{20}$

Pengertian lain tentang pendekatan diberikan oleh Milan Rianto dan kawan-kawan, bahwa pendekatan pembelajaran merupakan seperangkat wawasan yang secara sistematis digunakan sebagai landasan berpikir dalam menentukan strategi, metode, dan teknik (prosedur) dalam mencapai target atau hasil tertentu sesuai dengan tujuan yang telah ditetapkan. Pendekatan juga dapat diartikan sebagai suatu perspektif atau cara pandang seseorang dalam menyikapi sesuatu. ${ }^{21}$ Sri Anita W. yang mengutip pendapat Fred Percival dan Henry Ellington juga menyatakan bahwa pendekatan selalu berorientasi pada lembaga, guru dan peserta didik. Menurut mereka ketepatan dalam pemilihan suatu pendekatan akan menjadi pedoman atau orientasi dalam pemilihan komponen kegiatan pembelajaran lainnya terutama strategi dan metode pembelajaran. ${ }^{22}$

Dilihat dari jenisnya, pendekatan pembelajaran terbagi pada dua jenis yaitu: (1) pendekatan pembelajaran yang berorientasi atau berpusat pada siswa (student centered approach) dan (2) pendekatan pembelajaran yang berorientasi atau berpusat pada guru (teacher centered approach). Menurut Milano dan kawankawan, pendekatan yang berorientasi kepada guru dapat dinamakan pembelajaran konvensional di mana hampir semua kegiatan pembelajaran dikendalikan oleh guru dan staf lembaga pendidikan. Karakteristik dari pendekatan ini proses belajar mengajar atau proses komunikasi berlangsung di dalam kelas

\footnotetext{
${ }^{20}$ Sri Anita W "Modul Strategi Pembelajaran," lihat epository.ut.ac.id/4401/2/PEFI4201-M1.pdf (diakses pada tanggal 20 Sepetember 2018), 9.

${ }^{21}$ Milan Rianto dkk, Pendekatan, Strategi dan Metode Pembelajaran: Bahan Ajar Diklat Mata Pelajaran Pendidikan Kewarganegaraan SMA Jenjang Dasar (Departemen Pendidikan Nasional Direktorat Jenderal Peningkatan Mutu Pendidik dan Tenaga Kependidikan Pusat Pengembangan Penataran Guru IPS dan PMP Malang, 2006), 16.

${ }^{22}$ Sri Anita W, "Modul Strategi Pembelajaran," lihat epository.ut.ac.id/4401/2/PEFI4201-M1.pdf (diakses pada tanggal 20 Sepetember 2018), 9.
} 
dengan metode ceramah secara tatap muka (face to face) yang dijadwalkan oleh sekolah. ${ }^{23}$

Sementera, pendekatan pembelajaran yang berorientasi kepada peserta didik merupakan sistem pembelajaran yang menunjukkan dominasi peserta didik selama kegiatan pembelajaran dan guru hanya sebagai fasilitator, mediator, pembimbing dan pemimpin. Karakteristiknya berorientasi pada peserta didik di mana kegiatan pembelajaran beragam dengan menggunakan berbagai macam sumber belajar, metode, media, dan strategi secara bergantian sehingga serama proses pembelajaran peserta didik berpartisipasi aktif baik secara individu maupun kelompok. ${ }^{24}$

Dalam perspektif Islam, ada beberapa pendekatan yang dipakai dalam pendidikan Islam. Armai Arief di dalam Nurjannah mengatakan ada lima pendekatan yang dipakai dalam kegiatan proses belajar mengajar, yaitu pendekatan filosofis, induksi-deduksi, sosio-kultural, fungsional dan emosional. ${ }^{25}$ Pendekatan-pendekatan ini menurut Nurjannah didasari oleh teori barat dan teori Islam. Terkait penerapannya, pendekatan sosio-kultural sekarang ini lebih banyak digunakan oleh guru dalam praktik pembelajaran. Hal ini dipandang pada hakikat teori pendekatan itu sendiri, yang mana memandang manusia itu di samping sebagai makhluk individu juga sebagai makhluk sosial, karena manusia tidak dapat hidup sendiri, terpisah dari manusiamanusia yang lain. Manusia senantiasa hidup dalam kelompokkelompok kecil, seperti keluarga atau masyarakat. ${ }^{26}$ Pendekatan ini sangat efektif dalam membentuk sifat kebersamaan siswa

${ }^{23}$ Milan Rianto dkk, Pendekatan, Strategi dan Metode Pembelajaran: Bahan Ajar Diklat Mata Pelajaran Pendidikan Kewarganegaraan SMA Jenjang Dasar (Departemen Pendidikan Nasional Direktorat Jenderal Peningkatan Mutu Pendidik dan Tenaga Kependidikan Pusat Pengembangan Penataran Guru IPS dan PMP Malang, 2006), 16.

${ }^{24}$ Milan Rianto dkk. Pendekatan, Strategi dan Metode Pembelajaran: Bahan Ajar Diklat Mata Pelajaran Pendidikan Kewarganegaraan SMA Jenjang Dasar (Departemen Pendidikan Nasional Direktorat Jenderal Peningkatan Mutu Pendidik dan Tenaga Kependidikan Pusat Pengembangan Penataran Guru IPS dan PMP Malang, 2006), 16.

${ }^{25}$ Nurjannah Rianie, "Pendekatan dan Metode Pendidikan Islam: Sebuah Perbandingan dalam Konsep Teori Pendidikan Islam dan Barat," Management og Education 1, No 2. (2014).

${ }^{26}$ Nurjannah Rianie, "Pendekatan dan Metode Pendidikan Islam: Sebuah Perbandingan dalam Konsep Teori Pendidikan Islam dan Barat," Management og Education 1, No 2. (2014), 
dalam lingkungannya, baik di sekolah maupun masyarakat. Tak sebatas itu, pendekatan inipun juga tertuang dalam Alquran yang berbunyi:

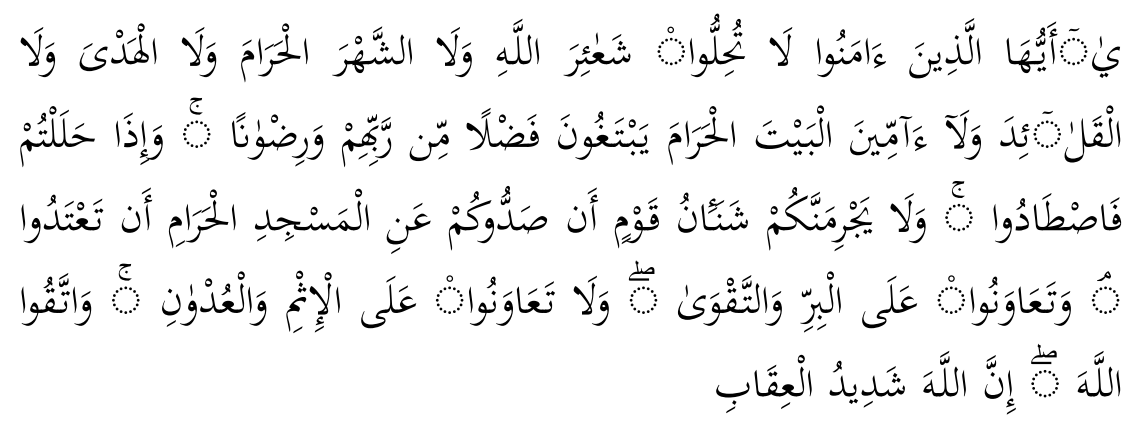

Artinya: "Hai orang-orang yang beriman, janganlah kamu melanggar syi'ar-syi'ar Allah dan jangan melanggar kehormatan bulan-bulan haram, jangan (mengganggu) binatang-binatang had-ya, dan binatang-binatang qalaa-id, dan jangan (pula) mengganggu orang-orang yang mengunjungi Baitullah sedang mereka mencari kurnia dan keredhaan dari Tuhannya dan apabila kamu Telah menyelesaikan ibadah haji, Maka bolehlah berburu. dan janganlah sekali-kali kebencian(mu) kepada sesuatu kaum Karena mereka menghalang-halangi kamu dari Masjidilharam, mendorongmu berbuat aniaya (kepada mereka). dan tolong-menolonglah kamu dalam (mengerjakan) kebajikan dan takwa, dan jangan tolong-menolong dalam berbuat dosa dan pelanggaran. dan bertakwalah kamu kepada Allah, Sesungguhnya Allah amat berat siksa-Nya." (Al-Maidah [5]: 2)

Terkait ayat di atas, berdasarkan pada pendekatan ini, menurut Nurjannah dalam tataran paktis, maka materi yang dipersiapkan untuk disampaikan kepada anak didik adalah materi yang sesuai dengan kebutuhan peserta didik dalam kehidupan bermasyarakat. Karena harus disadari sepenuhnya bahwa materi pelajaran yang disampaikan kepada anak didik tidak hanya sekedar untuk memajukan aspek kognitifnya, tetapi juga untuk kelangsungan hidupnya di masa mendatang. ${ }^{27}$

Jika dilihat dari pengertian, contoh, jenis dan karakteristik dari pendekatan pembelajaran di atas, dapat ditarik suatu pendangan umum yang jelas, bahwa pendekatan pembalajaran

${ }^{27}$ Nurjannah Rianie, "Pendekatan dan Metode Pendidikan Islam: Sebuah Perbandingan dalam Konsep Teori Pendidikan Islam dan Barat," Management og Education 1, No 2. (2014), 
diartikan sebagai titik tolak atau sudut pandang kita terhadap proses pembelajaran, yang merujuk pada pandangan tentang terjadinya suatu proses yang sifatnya masih sangat umum. Dan di dalamnya mewadahi, mengilhami, menguatkan, dan melatari metode pembelajaran dengan cakupan teoretis tertentu.

\section{Apa Itu Model Pembelajaran?}

Setelah sebelumnya membahas beberapa pengertian strategi, dan pendekatan. Maka, akan diberikan paparan singkat terkait berbagai pengertian dan pandangan tentang model pembelajaran. Menurut Muhammad Fathurrohman, istilah model pembelajaran acapkali dikaitkan dan disamakan dengan istilah strategi. Namun, pada penuturannya, terdapat perbedaan dari kedua istilah tersebut. Perbedaan umum dari model pembelajaran bahwa model pembelajaran dapat dipahami sebagai suatu kerangka konseptual yang digunakan sebagai pedoman dalam melakukan suatu kegiatan. Sementara, strategi sebagai turunan dari model pembelajaran. ${ }^{28}$

Terkait pengertian model pembelajaran, Muhammad Fathurrohman dengan menyertakan pendapat Joyce dan Weil yang mengatakan bahwa model pembelajaran adalah sebagai suatu perencanaan atau suatu pola yang digunakan sebagai pedoman dalam melaksanakan pembelajaran. ${ }^{29}$ Tergambar denga jelas, dari pengertian yang diberikan oleh Muhammad Fathurrohman tersebut, bahwa model pembelajaran dapat dimaknai suatu kerangka konseptual, yang dapat dijadikan acuan atau pedoman oleh pemangku pendidikan guna mengaplikasi suatu kegiatan pembelajaran.

Terkait pengertian dan pemaknaan model pembelajaran bersifat umum, Sagala dalam Fathurroman juga memberikan keterangan, bahwa, model pembelajaran dapat dipahami juga sebagai: 1) suatu tipe atau desain; 2) suatu deskripsi atau analogi yang dapat dengan lansung diamati; 3) suatu sistem asumsiasumsi, data-data dan inferensi-inferensi yang digunakan menggambarkan secara sistematis atau objek atau peristiwa; 4) suatu desain yang disederhanakan; 5) suatu deskripsi dari suatu

\footnotetext{
${ }^{28}$ Muhammad Fathurroman, Model-model Pembelajaran Inovatif (Jogjakarta: Ar-Ruzz Media, 2015), 29.

${ }^{29}$ Muhammad Fathurroman, Model-model Pembelajaran Inovatif (Jogjakarta: Ar-Ruzz Media, 2015), 30.
} 
sistem yang mungkin atau imajiner; 6) penyajian yang diperkecil agar dapat menjelaskan dan menunjukkan sifat bentuk aslinya. ${ }^{30}$

Pengertian berikutnya terkait model pembelajaran, diberikan oleh Endang Mulyatiningsih, menurutnya, model merupakan suatu istilah yang digunakan untuk menggambarkan penyelenggaraan proses belajar mengajar dari awal sampai akhir. Model pembelajaran mencerminkan penerapan suatu pendekatan, strategi, metode, teknik, ataupun taktik pembelajaran secara sekaligus untuk mencapai tujuan yang telah ditentukan. Terlihat dari pengertian ini, bahwa model pembelajaran lebih bersifat umum, bahkan model lebih umum dari pendekatan dan strategi. ${ }^{31}$

Guna lebih memperjelas hal ini, Udin dalam Muyatiningsih, juga memberi keterangan tentang model pembelajaran berupa konsep umum. Menurutnya, model pembelajaran ialah kerangka konseptual yang melukiskan prosedur yang sistematis dalam mengorganisasikan pengalaman belajar untuk mencapai tujuan tertentu. Dalam penuturannya juga, fungsi model pembelajaran sebagai pedoman bagi guru dalam merencanakan dan melaksanakan kegiatan belajar mengajar. Dengan demikian, satu model pembelajaran dapat menggunakan beberapa metode, teknik dan taktik pembelajaran sekaligus. $^{32}$

Pandangan yang sama oleh Rusman terkait hal ini, bahwa model pembelajaran dapat dijadikan pola pilihan, artinya, para guru boleh memilih model pembelajaran yang sesuai dan efesien untuk mencapai tujuan pendidikan. ${ }^{33}$

Elaborasi terkait hal ini, Fathurrohman menyatakan bahwa di dalam model pembelajaran terdapat atribut-atribut seperti adanya basis yang koheren atau sebuah sudut pandang tentang apa yan harusnya dipelajari dan bagaimana siswa belajar. Dengan begitu, dapat dipastikan bahwa penggunaan model pembelajaran haruslah sesuai dengan materi pelajaran. Selain atribut-atribut tersebut, Fathurrohman juga menyatakan bahwa di dalam model pembelajaran terdapat ciri-ciri yang bisa dikenali

\footnotetext{
${ }^{30}$ Muhammad Fathurroman, Model-model Pembelajaran Inovatif (Jogjakarta: Ar-Ruzz Media, 2015), 29.

${ }^{31}$ Endang Mulayiningsih, "Pembelajaran PAIKEM" (Depok: Direktorat Jenderal Peningkatan Mutu Pendidik dan Tenaga Kependidikan).

${ }^{32}$ Endang Mulyatiningsih, "Pembelajaran PAIKEM" (Depok: Direktorat Jenderal Peningkatan Mutu Pendidik dan Tenaga Kependidikan).

${ }^{33}$ Rusman, Model-model Pembelajaran: Mengembangkan Pfofesionalisme Guru (Jakarta: PT Raja Grafindo Persada, 2016), 131-132.
} 
seperti: 1) rasionalti dan logis yang disusun oleh para pengembang model pembelajaran, 2) memiliki landasan pemikiran yang kuat mengenai tujuan pembelajaran yang akan dicapai, 3) tingkah laku mengajar yang diperlukan untuk penerapan model, 4) lingkungan belajar yang kondusif diperlukan untuk tujuan pembelajaran. Kemudian ciri-ciri inilah yang menurut Fathorrohman mengindikasikan bahwa model pembelajaran memiliki konsep pertimbangan ilmiah karena besandarkan pada / konsep keilmuan dan memiliki prosedur sistematik. ${ }^{34}$

Selain itu, menurut Rusman di dalam model pembelajaran terdapat dasar pertimbangan pemilihan model pembelajaran. Beberapa dasar ini diperlukan untuk mengidentifikasi model pembelajaran yang akan digunakan oleh guru dalam kegiatan pembelajaran. Beberapa pertimbangan dasar tesebut yaitu: pertama, pertimbangan yang berhubungan dengan bahan atau meteri pembelajaran. Kedua, pertimbangan dari sudut peserta didik atau siswa. Dan terakhir, pertimbangan lainnya yang bersifat non-teknis. ${ }^{35}$ Tak sebatas dasar pertimbangan, Rusman juga mengidentifiaksi beberapa ciri-ciri model pembelajaran sebagai berikut:

a) Berdasarkan pendidikan dan teori belajar dari para ahli tertentu. Sebagai contoh, model penelitian kelompok disusun oleh Herbert Thelen dan berdasarkan Jhon Dewey. Model ini dirancang untuk melatih partisipasi dalam kelompok secara demokratis.

b) Mempunyai misi atau tujuan pendidikan tertentu, misalnya model berfikir induktif dirancang untuk mengembangkan proses berfikir induktif.

c) Dapat dijadikan pedoman untuk perbaikan kegiatan belajar mengajar di kelas, misalnya model Synectic dirancang untuk memperbaiki kteativitas dalam pelajaran mengarang.

d) Memiliki bagian-bagian model yang dinamakan: (1) urutan langkah-langkah pembelajaran (syntax); (2) adanya prinsiprinsip reaksi; (3) sistem sosial; dan (4) sistem pendukung. Keempat bagian tersebut merupakan pedoman praktis bila guru akan melaksanakan suatu model pembelajaran.

\footnotetext{
${ }^{34}$ Muhammad Fathurroman, Model-model Pembelajaran Inovatif (Jogjakarta: Ar-Ruzz Media, 2015), 31.

${ }^{35}$ Rusman, Model-model Pembelajaran: Mengembangkan Profesionalisme Guru (Jakarta: PT Raja Grafindo Persada, 2016), 132.
} 
e) Memiiki dampak akibat terapan model pembelajaran. dampak tersebut meliputi: (1) Dampak pembelajaran,yaitu hasil belajar yang dapat diukur; (2) Dampak pengiring, yaitu hasil belajar jangka panjang.

f) Membuat persiapan mengajar (desain instruksional) dengan pedoman model pembelajaran yang dipilihnya. ${ }^{36}$

Menilik dari beberapa pengertian di atas, tentang model pembelajaran, dapat diketahui secara kongkret, bahwa model pembelajaran adalah kerangka konseptual yang memilki dasar dari pembelajaran, untuk digunakan oleh guru/pendidik sebagai acuan/pedoman dalam kegiatan pembelajaran di kelas, termasuk di dalamnya dapat mencakup strategi, beberapa metode, teknik dan taktik pembelajaran sekaligus.

\section{E. Metode Pembelajaran}

Setelah membahas pengertian pendekatan, strategi, dan model pembelajaran, maka, akan dibahas juga beberapa pengertian dan pandangan tentang metode pembelajaran.

Secara definitif, metode pembelajaran adalah suatu cara atau jalan yang ditempuh yang sesuai dan serasi untuk menyajikan suatu hal sehingga akan tercapai suatu tujuan pembelajaran yang efektif dan efisien sesuai dengan yang diharapkan. ${ }^{37}$ Menurut Oemar Hamalik, metode adalah "Cara untuk menyampaikan materi pembelajaran dalam upaya mencapai tujuan kurikulum." Interpretasi dari pengertian ini menunjukkan bahwa metode pembelajaran ialah 1) cara, 2) untuk menyampaikan, 3) materi pembelajaran, 4) sebagai upaya mencapai tujuan kurikulum. Hal ini juga menegaskan jika dalam metode ada prosedur/langkah-langkah. ${ }^{38}$ Definisi yang serupa terkait metode adalah suatu cara oleh Pupuh Fathurrohman, yang mendefinisikan bahwa, metode pembelajaran ialah suatu cara yang dipergunakan untuk mencapai tujuan pembelajaran yang telah ditetapkan. ${ }^{39}$

\footnotetext{
${ }^{36}$ Rusman, Model-model Pembelajaran: Mengembangkan Pfofesionalisme Guru (Jakarta: PT Raja Grafindo Persada, 2016), 136.

${ }^{37}$ Salafudin, "Metode Pembelajaran Aktif Ala Rasulullah: Pembelajaran yang Membangkitakan Motivasi : (Suatu Metode Pembelajaran dari Hadis),“ Forum Tarbiyah 9, No. 2 ( 2011).

${ }^{38}$ Oemar Hamalik, Kurikulum dalam Pembelajaran (Jakarta: Bumi Aksara, 2009), 26-27.

${ }^{39}$ Pupuh Fathurrohman, Strategi Belajar Mengajar (Bandung: PT Refika Aditama, 2014), 15.
} 
Meninjau dari beberapa pengertian tersebut, secara implisit metode merupakan hal yang tidak terpisahkan dari kegiatan belajar mengajar, dan metode juga merupakan suatu cara untuk mencapai tujuan pembelajaran. Hal ini bisa dilihat dari pernyataan Pupuh Fathurrohman yang menyatakan bahwa bagi seorang guru menguasai metode merupakan keniscayaan, sebab seorang guru tidak akan dapat mengajar dengan baik apabila ia tidak mengusai metode secara tepat. ${ }^{40}$ Di dalam Alquran juga tertuang bagaimana pentingnya metode pembelajaran yang harus digunakan oleh guru. Berikut ayat Alquran terkait pentingnya metode dalam pembelajaran:

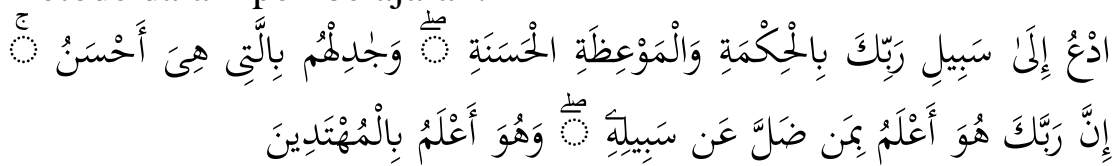

Artinya : "Serulah (manusia) kepada jalan Tuhan-mu dengan hikmah dan pelajaran yang baik dan bantahlah mereka dengan cara yang baik. Sesungguhnya Tuhanmu dialah yang lebih mengetahui tentang siapa yang tersesat dari jalan-Nya dan dialah yang lebih mengetahui orang-orang yang mendapat petunjuk." (Qs: Al-Nahl [16]: 125).

Ayat di atas menurut Salafudin secara implisit menerangkan bahwa terdapat beberapa metode pembelajaran yang terkadung di dalamnya seperti: hikmah (kebijaksanaan), mau'izoh hasanah (nasihat yang baik), dan mujadalah (dialog dan debat). Demikian juga dalam hadis Nabi, banyak terkandung beragam metode pembelajaran yang dicontohkan oleh Nabi Muhammad saw. Salah satunya adalah hadis yang berbunyi:

"Mudahkanlah dan janganlah kaти mempersulit. Gembirakanlah dan janganlah kamu membuat mereka lari" (H.R. Bukhari, Kitab al-'Ilm, No. 67). ${ }^{41}$

Kemudian terkait metode diartikan suatu cara, Abdul Majid juga mendefinisikan demikian. Menurutnya, metode adalah cara yang digunakan untuk mengimplementasikan rencana yang sudah disusun dalam kegiatan nyata, agar tujuan yang telah disusun tercapai secara optimal. Penjabarannya lebih lanjut olehnya,

\footnotetext{
${ }^{40}$ Pupuh Fathurrohman, Strategi Belajar Mengajar (Bandung: PT Refika Aditama, 2014), 15.

${ }^{41}$ Salafudin, "Metode Pembelajaran Aktif Ala Rasulullah: Pembelajaran yang Membangkitakan Motivasi : (Suatu Metode Pembelajaran dari Hadis),“ Forum Tarbiyah 9, No. 2 (2011).
} 
bahwa metode memegang peranan penting terhadap keberhasilan suatu pembelajaran. ${ }^{42}$

Pemaknaan yang sama perihal metode suatu cara, juga dikemukakan oleh Wina Sanjaya. Dalam penjebarannya, bahwa metode adalah sebagai alat/cara yang digunakan untuk mengimplementasikan rencana dan strategi yang telah tersusun, agar tercapainya tujuan pembelajaran secara maksimal. ${ }^{43}$

Endang Mulyatningsih pun memberikan kesimpulan yang serupa. Dalam keterangannya, metode pembelajaran merupakan sebuah cara yang digunakan guru untuk melaksanakan rencana yaitu mencapai tujuan pembelajaran yang sudah disusun dalam bentuk kegiatan nyata atau praktis. ${ }^{44}$

Selanjutnya untuk mengidentifikasi secara jelas terkait metode pembelajaran, Nurhidayati mengemukakan, bahwa ada beberapa hal yang perlu diperhatikan dalam memilih metode, yaitu: 1. Tujuan pembelajaran, selain kompetensi sesuai bidang studi juga perlu dikembangkan pendidikan karakter 2. Karakteristik materi pembelajaran 3. Jenis/bentuk kegiatan 4. Ukuran kelas 5. Kepribadian dan kemampuan guru 6. Karakteristik siswa 7. Waktu 8. Sarana dan prasarana yang tersedia. $^{45}$ Beberapa hal ini harus dilaksanakan oleh seorang guru, terkait bebebrapa faktor ini sangat berpengaruh terhadap pelaksanaan metode pembelajaran. Selain itu, guna mencapai tujuan pembelajaran yang optimal.

Kemudian, untuk lebih mengetahui dan memahami lebih jauh terkiat dengan metode, Abdul Majid menunjukkan jenisjenis metode pembelajaran yang sudah populer dan biasa digunakan oleh guru dalam kegiatan pembelajaran. Di antara jenis-jenis metode tersebut seperti: 1) metode ceramah, 2) metode tanya jawab, 3) metode resitasi, 4) metode drill (latihan), 5) metode diskusi, 6) metode role playing dan lain-lain.

Sementara, Nurhidayati menambahkan jenis-jenis metode pembelajaran yang di antaranya seperti: a) metode debat, b)metode simposium, c) metode jigsaw, d) metode investigasi, e)

${ }^{42}$ Abdul Majid, Stategi Pembelajaran (Bandung: PT Remaja Rodakarya, 2016), 193.

${ }^{43}$ Wina Sanjaya, Strategi Pembelajaran: Berorientasi Standar Proses Pendidikan (Jakarta: Kencana 2016), 147.

${ }^{44}$ Endang Mulyatiningsih, "Pembelajaran PAIKEM" (Depok: Direktorat Jenderal Peningkatan Mutu Pendidik dan Tenaga Kependidikan).

${ }^{45}$ Nurhidayati, "Metode Pembelajaran Interaktif," disampaikan pada "Seminar Metode Pembelajaran" bekerjasama dengan mahasiswa KKN-PPL UNY tahun 2011 di SMP N 2 Depok 1. 
metode pemecahan masalah (problem solving), f) metode mind mapping, g) metode student team-achievement devisions, $\mathrm{h}$ ) metode team-game- tournament, i) metode make- a match dan lain-lain.

Dari beberapa pengertian dan pendapat oleh tokoh-tokoh di atas, terkait definisi metode pembelajaran, maka, dapat diperjelas pengertian metode pembelajaran yaitu cara atau suatu jalan yang digunakan oleh guru untuk mencapai tujuan pembelajaran. Kemudian, di dalamnya terdapat prosedur/tahapan untuk mengimplementasikan model atau strategi pembelajaran. Selanjutnya, jika dilihat dari manfaat dan pentingnya metode, bahwa, seorang guru wajib menggunakan metode pembelajaran, karena makin baik metode itu, makin efektif pula pencapaian tujuan. Dengan demikian tujuan pembelajaran merupakan faktor utama dalam menetapkan baik tidaknya penggunaan suatu metode.

\section{F. Analisis Perbedaan Istilah Strategi, Pendekatan, Model Dan Metode Pembelajaran}

Setelah membahas pengertian istilah atau term strategi, pendekatan, model dan metode pembelajaran. Maka, akan dikaji dan dianalisis secara komprehensif dan kontekstual dari masingmasing istilah tersebut. Hal ini perlu dilakukan untuk memetakan, dan memperjelas pengertian dan makna dari masing-masing istilah tersebut, agar tidak terjadi lagi kerancuan dalam mengggunakan istilah-istilah tersebut di dunia literasi dan dunia pendidikan khususnya. Di bawah ini akan dipaparkan secara rinci batasan istilah tentang strategi, pendekatan, model dan metode pembelajaran.

Dalam Islam, persoalan pendidikan banyak dibicarakan dalam Alquran antara lain: dalam Surat al-An'am [6]:38, Surat alNahl [16]:18, dan sejumlah ayat lainnya. Alquran mengisyaratkan pula tentang pentingnya sumber pendukung dalam mengimplementasikan konsep-konsep pendidikan dalam Alquran, yaitu sosok orang yang mampu menjadi contoh dan suri tauladan dalam kehidupan manusia sehari-hari, yaitu Nabi Muhammad saw. ${ }^{46}$ Terkait beberapa istilah tersebut, jika dikaitkan dalam perspektif Islam, maka akan terkait pada potensi

\footnotetext{
${ }^{46}$ Salafudin, "Metode Pembelajaran Aktif Ala Rasulullah: Pembelajaran yang Membangkitakan Motivasi : (Suatu Metode Pembelajaran dari Hadis),“ Forum Tarbiyah 9, No. 2 (2011).
} 


\section{|Rekssiana}

fitrah manusia yang condong kepada nilai-nilai kebenaran dan kebijakan guna dapat memfungsikan dirinya sebagai manusia. Hal ini juga dapat disandarkan pada ayat Alquran sebagai berikut:

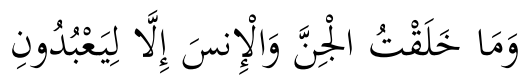

Artinya : "Dan Aku tidak menciptakan jin dan manusia melainkan supaya mereka mengabdi kepada-Ku." (Q.S: AlZariyat [51]: 56)

Kemudian pada ayat lain yang berbunyi:

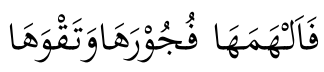

Artinya : "Maka Allah mengilhamkan kepada jiwa itu (jalan) kefasikan dan ketakwaannya." (Q.S: Al-Syams [91]:8).

Menurut Salafudin, secara implisit ayat-ayat di atas mengindikasikan bagaimana manusia yang siap menjalankan risalah yang dibebankan kepadanya sebagai khalifah di muka bumi. Oleh karena itu, pendidikan merupakan suatu proses membina seluruh potensi manusia sebagai makhluk yang beriman dan bertakwa, berpikir dan berkarya, sehat, kuat, dan berketerampilan tinggi untuk kemaslahatan diri, masyarakat, dan lingkungannya. Untuk mencapai tujuan pendidikan sebagaimana yang diharapkan, diperlukan suatu pendekatan, strategi, model dan metode pembelajaran. ${ }^{47}$

Menurut Endang Mulyatinginsih, dalam kegiatan pembelajaran, ada beberapa istilah yang sering digunakan untuk menggambarkan situasi belajar-mengajar. Dan istilah-istilah ini dalam penggunaannya sering tidak kosisten atau overlapping. Untuk membedakan dan memperjelas perbedaan masing-masing Mulyatiningsih membedakan masing-masing istilah tersebut secara kontekstual. Mulyatiningsih mengartikan model pembelajaran merupakan istilah yang digunakan untuk menggambarkan penyelenggaraan proses belajar mengajar dari

${ }^{47}$ Salafudin, "Metode Pembelajaran Aktif Ala Rasulullah: Pembelajaran yang Membangkitakan Motivasi : (Suatu Metode Pembelajaran dari Hadis),“ Forum Tarbiyah 9, No. 2 (2011). 
awal sampai akhir. $^{48}$ Dalam model pembelajaran sudah mencerminkan penerapan suatu pendekatan, metode, teknik atau taktik pembelajaran sekaligus.

Guna memperjelas hal ini, Mulyatiningsih pun mengutip keterangan yang diberikan Udin, bahwa menurutnya model pembelajaran bersifat konseptual yang menggambarkan prosedur yang sistematis dalam mengorganisasikan pengalaman belajar untuk mencapai tujuan tertentu. ${ }^{49}$ Fungsi model sebagai pedoman bagi guru merencanakan dan melaksanakan kagiatan pembelajaran di kelas. Hal ini menandakan bahwa dalam model pembelajaran dapat menggunakan beberapa metode, teknik dan taktik pembelajaran sekaligus.

Sementara, terkait istilah strategi dan pendekatan, Mulyatiningsih terlihat seperti menyamakan kedua hal tersebut. Dalam pandangannya, pendekatan merupakan istilah yang melingkupi seluruh proses pembelajaran. Terkait kedua hal ini dinyatakan sama, karena menurutnya, kedua istilah tersebut (pendekatan dan strategi pembelajaran) sama-sama berorientasi untuk menjelaskan bagaimana proses seorang guru mengajar dan peserta didik belajar dalam mencapai tujuan. ${ }^{50}$

Penjelasan selanjutnya oleh Mulyatiningsih, level di bawah pendekatan dan strategi adalah metode pembelajaran. Jika model masih bersifat konseptual, dan strategi masih bersifat sederatan prosedur, maka metode pembelajaran sudah bersifat praktis untuk diterapkan. Cakupan metode pembelajaran lebih kecil daripada strategi atau model pembelajaran. ${ }^{51}$

Untuk lebih memberikan kejelasan terkait perbedaan dari masing-masing istilah, Ahwan Fanani juga mencoba membedakan dan memberikan klasifikasi terkait istilah strategi dan metode. Dalam studinya, Fanani mencoba membedakan kedua istilah tersebut dengan menggunakan pendekatan terkait pemberian definisi, kemudian mencari substansi dan ciri khas dari kedua istilah, dan terakhir melihat relevansi dari kedua

\footnotetext{
${ }^{48}$ Endang Mulyatiningsih, "Pembelajaran PAIKEM" (Depok: Direktorat Jenderal Peningkatan Mutu Pendidik dan Tenaga Kependidikan).

${ }^{49}$ Endang Mulatiningsih, "Pembelajaran PAIKEM" (Depok: Direktorat Jenderal Peningkatan Mutu Pendidik dan Tenaga Kependidikan).

${ }^{50}$ Endang Mulatiningsih, "Pembelajaran PAIKEM" (Depok: Direktorat Jenderal Peningkatan Mutu Pendidik dan Tenaga Kependidikan).

${ }^{51}$ Endang Mulatiningsih, "Pembelajaran PAIKEM" (Depok: Direktorat Jenderal Peningkatan Mutu Pendidik dan Tenaga Kependidikan).
} 


\section{|Rekssiana}

istilah tersebut. $^{52}$ Jika ditilik lebih jauh, Ahwan Fanani di awal tulisannya terlihat seperti masih memiliki kesangsian alam memberikan klasfikasi, namun di akhir kesimpulan tulisannya, Fanani mengartikan istilah metode dan strategi mengandung konsep masing-masing. Jika dilihat dari persoalan konsep kedua istilah tersebut, dinyatakan olehnya masih bersifat konstruktif, artinya dirumuskan berdasarkan pemahaman mengenai substansi dari masing-masing istilah dan sifat khasnya masing-masing.

Pasal kesangksiannya jika ditinjau dari permaslahanpermaslahan yang selama ini terjadi, terkait pemaknaan dari masing-masing istilah, dan terkait konsep yang dikandung oleh istilah strategi dan metode dalam konteks pembelajaran. Hal ini menuntut adanya analisis secara hati-hati agar kerancuan yang muncul bisa diurai. Kemudian, jika ditinjau pada kesimpulan terakhir pada studinya, bahwa pemahaman mengenai hubungan strategi dan metode tidak tunggal. Setidaknya ada lima pemahaman tentang substansi strategi dan metode pembelajaran dan bagaimana kedua istilah tersebut digunakan. Terkait hal ini Fanani cenderung untuk lebih menyederhanakan istilah dalam pembelajaran yang menyangkut "how". Meskipun beberapa istilah mengandung sudut pandang yang berbeda, seperti pendekatan, model, dan teknik, namun istilah metode dan strategi bisa digunakan secara saling bergantian. Hal itu akan mempermudah bagi proses perencanaan pembelajaran dan menghilangkan polemik terhadap dua istilah yang substansinya bertumpang tindih dan sulit sekali. ${ }^{53}$

Terkait perihal ini pun, jika dianalisis lebih mendalam, dalam bab kesimpulan yang dituliskan oleh Fanani, pengertian strategi sebagai kerangka pembelajaran yang bersifat kerangka umum tersebut, masih belum menemukan validasi dari semua pihak. Pasalnya dalam keterangannya, Ismali misalnya, meskipun setuju untuk mengartikan strategi sebagai gambaran umum, namun contoh-contoh yang dikemukakan bersifat praktis. Level organisasi ini lebih mudah dijabarkan dalam praktik dibandingkan level yang lebih banyak, dengan membedakan strategi dan metode, tetapi pada sisi praktisnya masih terjadi over

${ }^{52}$ Ahwan Fanani, "Mengurangi Kerancuan Istilah Strategi dan Metode Pembelajaran," Jurnal Pendidikan Islam 8, No. 2 (2014), download.portalgaruda.org/article.php (diakses pada tanggal 12 Juni 2018).

${ }^{53}$ Ahwan Fanani, Mengurangi Kerancuan Istilah Strategi dan Metode Pembelajaran, Jurnal Pendidikan Islam 8, No. 2 (2014), download.portalgaruda.org/article.php (diakses pada tanggal 12 Juni 2018). 
lapping. Arah perbedaan istilah strategi dan metode tidak lagi memiliki relevansi teoritis maupun praktis. Hal inilah yang membuat adanya kesangsian dalam kesimpulan akhir dalam hal perbedaan antara strategi dan metode. Akan tetapi, dalam memaknai pendekatan, model dan tenik, Fanani turut membedakan ketiga istilah tersebut. ${ }^{54}$

Pada intinya Fanani dalam studinya membedakan masingmasing istilah. Dalam pandangannya, pendekatan menempati level teratas, berlanjut ke istilah strategi, dan disusul oleh metode. Namun dalam tataran aplikasinya, Fanani memberikan lisensi untuk menggunakan istilah strategi dan metode untuk bisa disejajarkan. Hal ini bisa dilakukan, karena, menurutnya upayaupaya untuk menjabarkan semua strategi dan metode selama ini masih belum berhasil dalam membedakan secara konklusif antara kedua istilah di atas. Penjelasan operasional keduanya belum memadai untuk melihat hubungan keduanya dalam praktek pembelajaran.

Penjelasan lebih lanjut dalam memberikan perbedaan dari masing-masing istilah tersebut, oleh Pebrina Dewika dkk, yang memberikan keterangan bahwa secara luas strategi dapat diartikan mencakup metode, cara pendekatan, pemakaian media belajar, pengelompokan siswa serta evaluasi hasil belajar yang dilakukan oleh guru sebagai pengelola kelas dalam proses belajar mengajar. Menurut mereka, strategi dapat diartikan sebagai pola umum kegiatan belajar mengajar yang memungkinkan siswa melakukan aktivitas emosional dan intelektual secara optimal untuk mencapai tujuan yang telah ditetapkan sebelumnya. ${ }^{55}$

Hal ini pun dapat diperjelas pada temuan mereka, seperti pada bab analisis data, terkait pengertian strategi diartikan sebagai suatu sistem yang di dalamnya dapat diaplikasikan oleh beberapa metode atau bersifat konseptual. Hal ini juga dapat dilihat pada hasil penelitian yang didapat, bahwa pengunaan beberapa metode seperti ceramah, demonstrasi, dan cooperative

${ }^{54}$ Ahwan Fanani, Mengurangi Kerancuan Istilah Strategi dan Metode Pembelajaran, Jurnal Pendidikan Islam 8, No. 2 (2014), download.portalgaruda.org/article.php (diakses pada tanggal 12 Juni 2018).

${ }^{55}$ Pebrina Dewika dkk, "Strategi Guru dalam Mengembangkan Kreativitas Siswa pada Pembelajaran Seni Tari di SMA Negeri 3 Payakumbuh," E-Jurnal Sendratasik FBS Universitas Negeri Padang, 2 No. 1 (2013). 
learning masuk ke dalam penerapan suatu strategi pembelajaran. ${ }^{56}$

Terkait hal membedakan strategi dan metode, dan memandang strategi masih bersifat umum, Hamzah B. Uno dkk turut mengakui, pasalnya menurut mereka, bahwa strategi harus mengandung penjelasan tentang metode/prosedur dan teknik yang digunakan selama proses pembelajaran berlansung. Dengan kata lain, menurut mereka bahwa strategi pembelajaran mengandung arti yang lebih luas dari metode dan teknik. Selain itu, secara terminologi, strategi diartikan oleh mereka, adalah cara-cara yang akan digunakan oleh pengajar untuk memilih kegiatan belajar yang akan digunakan sepanjang proses pembelajaran. Pemilihan suatu strategi dilakukan dengan mempertimbangkan situasi dan kondisi, sumber belajar, kebutuhan dan karakteristik peserta didik yang dihadapi dalam rangka mencapai tujuan pembelajaran. ${ }^{57}$

Tak sabatas itu, mengenai hal perbedaan, Uno dkk juga memperjelas adanya hubungan antara strategi, tujuan dan metode pembelajaran. Hal tersebut menurut meraka dapat digambarkan sebagai suatu kesatuan sistem yang bertitik tolak dari penentuan tujuan pembelajaran, pemilihan strategi, dan perumusan tujuan pembelajaran. Untuk lebih memperjelas lagi, Uno dkk juga menyertakan beberapa komponen pembelajaran, di mana beberapa komponen ini sudah ditulis oleh penulis pada $\boldsymbol{s u b} \boldsymbol{b} \boldsymbol{a b}$ pengertian strategi pembelajaran. ${ }^{58}$ Selanjutnya, komponenkomponen ini akan mendeskripsikan langkah-langkah dalam RPP di mana metode menjadi salah satu komponen dalam suatu strategi pembelajaran. Berikut bagan terkait ilustrasi keterangan perbedaan yang diberikan Hamzah B. Uno dkk. ${ }^{59}$

${ }^{56}$ Pebrina Dewika dkk, "Strategi Guru dalam Mengembangkan Kreativitas Siswa pada Pembelajaran Seni Tari di SMA Negeri 3 Payakumbuh," E-Jurnal Sendratasik FBS Universitas Negeri Padang, 2 No. 1 (2013).

${ }^{57}$ Hamzah. B. Uno, Model Pembelajaran Menciptakan Proses Belajar Mengajar yang Kreatif dan Efektif, (Jakarta: Bumi Aksara, 2011), 2.

${ }^{58}$ Lihat pada sub bab pengertian strategi pembelajaran dalam tulisan ini terkait komponen-komponen pembelajaran pada halaman 2-3. Liha juga Wina Sanjaya, Strategi Pembelajaran Berorientasi Standar Proses Pendidikan (Jakarta: Kencana, 2016), 135.

${ }^{59}$ Hamzah. B. Uno, Model Pembelajaran Menciptakan Proses Belajar Mengajar yang Kreatif dan Efektif, (Jakarta: Bumi Aksara, 2011), 4-7. 


\section{Bagan 1.1}

Substansi, Unsur, Pendekatan dan sasaran

Menurut B. Uno dkk

\begin{tabular}{lll}
\hline Substansi & Unsur & \multicolumn{2}{c}{ Pendekatan } & Sasaran \\
& & \\
\hline Strategi & Rencana Tindakan & - Rangkian Kegiatan \\
& & - Mencapai Tujuan \\
& & Pendidikan \\
& & - Metode Pemanfaatan \\
& & Sumber Daya \\
Metode & Cara & - Melaksanakan Strategi \\
& & \\
\hline
\end{tabular}

\section{Bagan. 1.1}

Jika menilik bagan di atas, dapat dikatakan bahwa Hamzah B. Uno dkk secara implisit memahami strategi sebagai sebuah kerangka umum. Hal itu membuat strategi bisa dijabarkan dalam banyak metode. Penjabaran terkait ini benar-benar utuh dan terlihat komprehensif, karena mencakup unsur-unsur pembelajaran seperti metode di dalamnya. Intinya, dalam hal ini dapat dikatakan strategi adalah sebagai rancangan unsur-unsur pembelajaran. ${ }^{60}$

Penjabaran mengenai perbedaan istilah-istilah ini, juga dikemukakan oleh Rusman. Sebelumnya, Rusman juga turut mengakui adanya tumpang tindih dalam memberikan makna dari masing-masing istilah tersebut. Untuk itu, Rusman memberikan penjabaran terkiat hal ini. Pertama, Rusman mengambil keterangan dari Kemp, Dick dan Caray yang menginterpretasikan strategi adalah suatu perangkat meteri dan prosedur pembelajaran yang digunakan secara bersama-sama untuk menimbulkan hasil belajar pada peserta didik. Kedua, pada titik pengimplementasian dari strategi, dapat menggunakan berbagai metode. Rusman mencontohkan, untuk menerapkan salah satu strategi pembelajaran seperti ekspositori bisa

${ }^{60}$ Ahwan Fanani, "Mengurangi Kerancuan Istilah Strategi dan Metode Pembelajaran," Jurnal Pendidikan Islam 8, No. 2 (2014), download.portalgaruda.org/article.php (diakses pada tanggal 12 Juni 2018). 


\section{|Rekssiana}

digunakan berbagai metode seperti metode ceramah, tanya jawab, bahkan diskusi. ${ }^{61}$

Terilihat dari keterangan ini, bahwa strategi berbeda dengan metode. Pada strategi, mengindikasikan dan menunjukkan pada sebuah perencanaan untuk mencapai sesuatu dan mengandur unsur-unsur di dalamnya termasuk metode itu sendiri. Intinya, metode bagian dari strategi pembelajaran.

Kemudian terhadap istilah pendekatan, Rusman mengartikan pendekatan sebagai titik tolak atau sudut pandang terhadap proses pembelajaran. Orientasi dari pemaknaan ini, bahwa pendekatan merujuk kepada pendangan tentang terjadinya suatu proses yang sifatnya masih sangat luas atau global. Dengan mengambil keterangan dari Roy Kallen, Rusman menyatakan dua jenis pendekatan dalam pembelajaran yaitu 1) pendekatan yang berpusat pada guru (teacher centered approach), dan 2) pendekatan yang berpusat pada siswa ( student centered approach). Dalam pendekatan pertama, atau yang juga disingkat sebagai $\boldsymbol{T C L}$, ini turunanya pada pembelajaran lansung (direct instruction) yang dapat juga dikenal dengan pembelajaran deduktif atau pembelajaran ekspository. Sedangkan pada pendekatan kedua, atau disebut juga $\boldsymbol{S C L}$ diturunkan pada inquiry dan discovery dan pembelajaran induktif. ${ }^{62}$

Meniliki penjabaran menganai ini, dapat diperjelas lagi bahwa pendekatan lebih umum dari strategi. Maksudnya, untuk mengaplikasikan suatu pendekatan pembelajaran dapat menggunakan strategi pembelajaran.

Istilah selanjutnya yang dibedakan oleh Rusman ialah istilah model pembelajaran. Model pembelajaran dimaknai oleh Rusman sebagai kerangka konseptual atau pola umum perilaku pembelajaran untuk suatu tujuan pendidikan. Lebih luas lagi, Rusman mengartikan model sebagai suatu rencana atau pola yang dapat digunakan untuk membentuk kurikulum, merancang bahanbahan pembelajaran dan membimbing pembelajaran di kelas. ${ }^{63}$

Dalam penjabarannya, Rusman mengaitkan jika lazimnya dalam model pembelajaran disusun berdasarkan berbagai prinsip

\footnotetext{
${ }^{61}$ Rusman, Model-model Pembelajaran: Mengembangkan Profesionalisme Guru (Jakarta: PT Raja Grafindo Persada, 2016), 132.

${ }^{62}$ Rusman, Model-model Pembelajaran: Mengembangkan Profesionalisme Guru (Jakarta: PT Raja Grafindo Persada, 2016), 132.

${ }^{63}$ Rusman, Model-model Pembelajaran: Mengembangkan Profesionalisme Guru (Jakarta: PT Raja Grafindo Persada, 2016), 133.
} 
atau pengetahuan. Dengan mengutip pendapat para ahli seperti Joyse dan Weil, yang menurut

mereka model pembelajaran disusun berdasarkan prinsipprinsip pembelajaran, psikologis, sosiologis, analisis sistem dan lain-lain yang mendukung. Uraian selanjutnya, terkait model pembelajaran, Rusman menyatakan bahwa berdasarkan teori belajar, model pembelajaran dapat dikelompokkan menjadi empat model pembelajaran seperti; 1) model pembelajaran interaksi sosial, 2) model pemrosesan informasi, 3) model personal, dan 4) model model modifikasi tingkah laku. ${ }^{64}$

Penjabaran selanjutnya terkait perbedaan istilah-istilah ini, oleh Siti Alimah, dan Aditya Marianti. Perbedaan yang mereka ungkapkan terkait hal ini, dapat sekiranya dilihat dari bagaimana Alimah dan Marianti mendefinisikan satu per satu makna dari istilah-istilah tersebut. Definisi pendekatan menurut mereka, lebih dipandang sebagai pola umum dari berbagai desain pembelajaran. Meninjau hal ini, bahwa pembelajaran berdasarkan dari rumusan yang berlandaskan pada teori belajar dan prinsip pembelajaran seperti konstruktivis, humanistik, Bruner, sibernetik, Ausubel, dan behavioristik. Hal inilah yang menyakinkan mereka bahwa pendekatan mengacu pada suatu pola umum pada desain pembelajaran. Pola umum yang mereka nyatakan juga dapat dimengerti, dari penerapannya. Lantaran bahwa pendekatan diterapkan secara nyata dalam proses pembelajaran melalui penggunaan strategi, model, metode, teknik, dan taktik pembelajaran yang sesuai dengan karakteristik pendekatan tersebut. $^{65}$

Terhadap strategi pembelajaran, dimaknai sebagai suatu cara yang dilakukan guru untuk mencapai tujuan pembelajaran. Istilah strategi menurut mereka juga masih bersifat umum, karena berisi tentang prinsip umum tentang karakteritik tertentu yang dapat diterapkan oleh guru. ${ }^{66}$ Untuk lebih memahami makna istilah ini, dapat diketahui juga melalui penerapannya. Strategi dapat diwujudkan dengan mempraktikkan prinsip-prinsip yang

\footnotetext{
${ }^{64}$ Rusman, Model-model Pembelajaran: Mengembangkan Profesionalisme Guru (Jakarta: PT Raja Grafindo Persada, 2016), 133.

${ }^{65}$ Siti Alimah, dan Aditya Marianti, "Jelajah Alam Sekitar: Pendekatan, Strategi, Model, dan Metode Pembelajaran Biologi Berkarakter untuk Konservasi," (Semarang: FMIPA Universitas Negeri Semarang, 2016), 16.

${ }^{66}$ Siti Alimah, dan Aditya Marianti, "Jelajah Alam Sekitar: Pendekatan, Strategi, Model, dan Metode Pembelajaran Biologi Berkarakter untuk Konservasi," (Semarang: FMIPA Universitas Negeri Semarang, 2016), 17.
} 
terdapat dalam strtagi tersebut. Misalnya, strategi inquiry menekankan pada prinsip pembelajaran dimana peserta didik mampu menggunakan dan menemukan konsep pengetahun dengan mandiri. Selain itu, pada praktiknya, menurut mereka strategi dengan melalui penggunaan metode pembelajaran yang didesain sesuai dan atau disesuaikan dengan karakteristiknya. ${ }^{67}$

Istilah selanjutnya yang bedakan adalah model dan metode pembelajaran. Bekenaan kedua istilah ini, bahwa pemaknaan dari model ialah suatu cara pembelajaran yang memiliki tujuan dan sintaks tertentu untuk mencapai target pembelajaran. Mereka memaparkan bahwa Model pembelajaran diciptakan dengan memperhatikan pendekatan, strategi, metode, teknik, dan taktik tertentu. Melihat hal ini model dipahami oleh mereka pola paling umum, karena pada suatu model menerapkan pendekatan, strategi dan metode. Contohnya yang mereka gambarkan adalah, model Eksperiential Jelajah Alam Sekitar (EJAS) merupakan model pembelajaran yang menerapkan pendekatan JAS, strategi inquiry, metode eksplorasi, observasi, percobaan, dan diskusi, dan teknik pembelajaran siswa aktif (active learning).

Kemudian, terkiat perihal metode, diartikan sebagai bentuk nyata dari implementasi sebuah strategi pembelajaran. Contohnya praktik metode ceramah merupakan salah satu bentuk nyata dari strategi tertentu dalam desain pembelajaran. Selanjutnya, teknik dimaknai sebagai langkah-langkah tertentu yang dijadikan oleh guru dengan melihat pertimbangan karakteristk peserta didik dan materi yang akan dipelajari. Misalnya guru memberikan perlakukan yang berbeda pada peserta didik aktif dan pasif. Hal inilah yang mereka sebut dengan teknik pembelajaran. Terakhir, ketika guru mengambil atau melakukan langkah-langkah khusus atau tertentu dengan mererapkan suatu gaya (style) khas atau karakteristik yang dimiliki guru, maka, itu disebut mereka dengan taktik pembelajaran. ${ }^{68}$ Jika diilustrasikan bagaimana gambaran dari analisis yang diberikan oleh Siti Alimah, dan Aditya Marianti, maka akan mengacu pada taksonomi di bawah ini:

${ }^{67}$ Siti Alimah, dan Aditya Marianti, “Jelajah Alam Sekitar: Pendekatan, Strategi, Model, dan Metode Pembelajaran Biologi Berkarakter untuk Konservasi," (Semarang: FMIPA Universitas Negeri Semarang, 2016), 17.

${ }^{68}$ Siti Alimah, dan Aditya Marianti, Jelajah Alam Sekitar: Pendekatan, Strategi, Model, dan Metode Pembelajaran Biologi Berkarakter untuk Konservasi (Semarang: FMIPA Universitas Negeri Semarang, 2016), 18. 


\section{Taksonomi/ Bagan oleh Siti Alimah, dan Aditya Marianti}

Bagan 2. 2

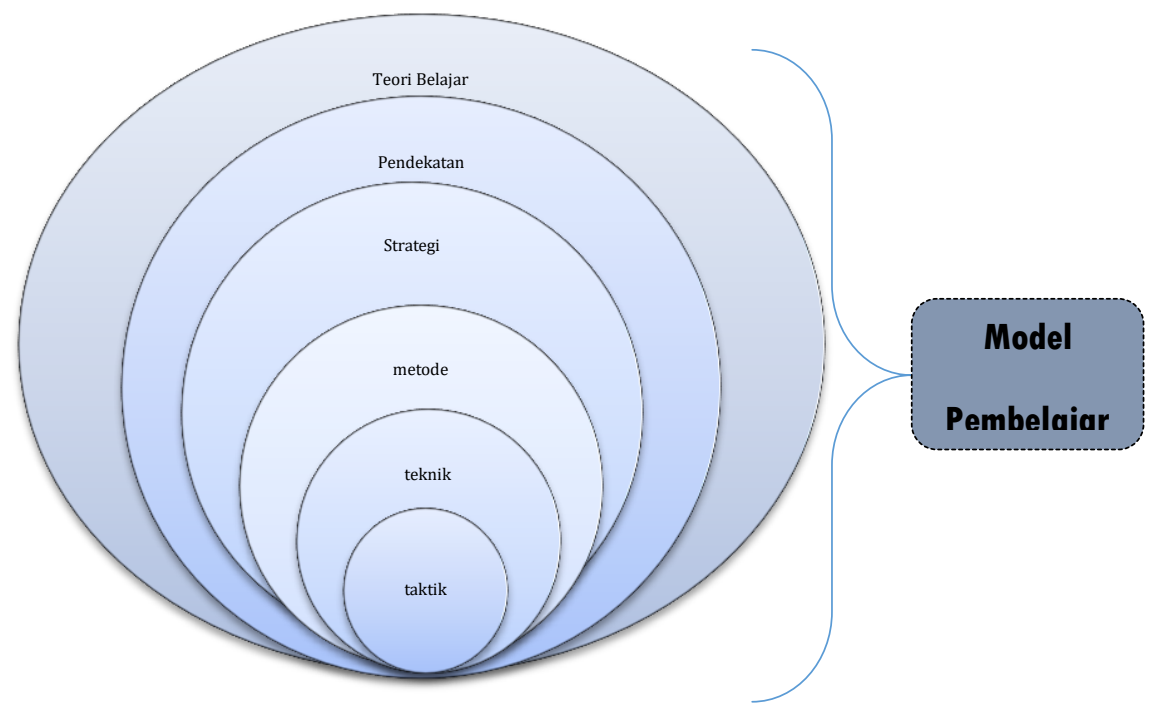

Menilik perihal perbedaan istilah-istilah yang telah dibahas dan dijabarkan oleh Alimah, dan Marianti, dapat dihasilkan penjelasan ringkas dan nyata, adanya perbedaan dari masingmasing makna dan pengertian. Perbedaan yang mereka nyatakan, dapat dilihat dari dua kategori, pertama, dilihat dari pengertian masing-masing istilah yang telah mereka ungkapkan di atas. Kedua, dilihat dari implementasi atau praktik dari masing-masing istilah tersebut. Dalam hal ini, dapat diuurutkan jika strategi, metode, teknik dan taktik merupakan bagian dari implementasi suatu pendekatan pembelajaran. Kemudian, jika dilihat secarah utuh dari penjebaran dan bagan yang telah tergambar di atas bahwa model pembelajaran menempati posisi paling atas, dan dimaknai sebagai pola paling umum dari istilah-sitilah yang lain. Hal ini juga mengindikasikan jika model pembelajaran dipandang sebagai pola paling umum dari istilah yang lain, karena model pembelajaran bersandarkan pada rumusan teori belajar tertentu. Kemudian, diikuti oleh pendekatan, srategi, metode dan disusul oleh teknik dan taktik pembelajaran.

Terkait analisis perbedaan dari masing-masing istilah, akan dikemukan suatu pandangan yang juga dikemukakan oleh Nurhidayati. Mengenai hal ini, Nurhidayati memberikan analisis perbedaan dari masing-masing istilah ini dengan menunjukkan batasan dan pengertian masing-masing istilah. Kemudian Nurhidayati mencoba mengklasifikasikan menjadi beberapa level 


\section{|Rekssiana}

dari masing-masing istilah tersebut. Terkait pengertian dari masing-masing istilah tersebut, urutan pertama yakni pengertian pendekatan yang diartikan olehnya sebagai suatu titik tolak atau sudut pandang mengenai terjadinya proses pembelajaran secara umum berdasarkan cakupan pratik pembelajaran tertentu. Kemudian menurutnya, pendekatan terbagai kepada dua jenis, yaitu student centered approach atau pendekatan yang berpusat pada siswa dan teacher centered approach yang dikenal juga pendekatan yang berpusat pada guru.

Selanjutnya, Nurhidayati mengidentifikasi bahwa level di bawah pendekatan adalah strategi pembelajaran. Strategi dapat diartikan sebagai suatu perencanaan yang berisi metode, atau serangkaian kegiatan yang didesain untuk mencapai suatu tujuan pendidikan. Setelah strategi, level berikutnya adalah metode. Metode sama halnya dengan tokoh-tokoh lain di atas yang menganggap bahwa metode ialah suatu cara dalam suatu pembelajaran. Selain itu, menurutnya, metode digunakan untuk merealisasikan strategi yang telah dirumuskan oleh guru. Dalam mempraktikkan suatu strategi pembelajaran memungkinkan untuk dapat diterapkan beberapa metode pembelajaran. Sebagai contoh, penerapan strategi discovery dapat digunakan: metode jigsaw, metode mind- mapping, metode example- non example, metode problem- solving dan lain-lain. Kemudian berlanjut pada level di bawah metode adalah teknik dan taktik pembelajaran. ${ }^{6}$

Taktik pembelajaran adalah gaya guru dalam melaksanakan metode atau teknik pembelajaran tertentu yang sifatnya individual. Mengenai hal ini, Hurhidayati turut menyamai pemaknaan yang diberikan oleh Mulyatiningsih Alimah, dan Marianti yang mengartikan taknik sebagai improvisasi guru dalam menggunakan metode, kemudian taktik dimaknai sebagai gaya (style) sesorang guru ketika menerapkan metode pembelajaran. $^{70}$

Dalam memberikan identifikasi model pembelajaran, Nurhidayati juga memaknainya sebagai pola paling umum, atau level teratas. Perihal ini dapat dilihat dari keterangannya yang memberikan perbedaan sitilah-istilah seperti: pendekatan,

${ }^{69}$ Nurhidayati, "Metode Pembelajaran Interaktif," disampaikan pada "Seminar Metode Pembelajaran" bekerjasama dengan mahasiswa KKN-PPL UNY tahun 2011 di SMP N 2 Depok 1.

${ }^{70}$ Nurhidayati, "Metode Pembelajaran Interaktif," disampaikan pada "Seminar Metode Pembelajaran" bekerjasama dengan mahasiswa KKN-PPL UNY tahun 2011 di SMP N 2 Depok 1 
strategi, metode, teknik dan taktik pembelajaran, karena istilahistilah ini dalam praktiknya harus menjadi satu kesatuan yang utuh guna tercapai atau terbentuknya suatu model pembelajaran.

Berdasarkan uraian di atas, dapat dipertegas bahwa model pembelajaran berisi unsur tujuan, tahap-tahap kegiatan, setting pembelajaran, kegiatan guru dan siswa, perangkat pembelajaran (sarana, bahan, dan alat yang diperlukan), hasil pembelajaran yang akan dicapai sebagai akibat proses belajar mengajar. Bahkan Nurhidayati mengatakan bahwa perancangan model pembelajaran hampir sama dengan penyusunan rencana pelaksanaan pembelajaran (RPP) yang lengkap dengan perangkatnya. ${ }^{71}$ Melihat dari penjelasan Nurhidayati tersebut, maka dapat diperjelas, bahwa masing-masing pengertian memiliki makna yang berbeda. Kemudian, pada tahap pelaksanaan dari masing-masing istilah, maka akan tergambarkan masing-masing istilah tersebut memilik posisi tertentu atau yang disebut dengan levelnya masing-masing. Model menempati level teratas, kemudian pendekatan, disusul oleh strategi dan bagian paling bawah yaitu teknik dan taktik.

Kemudian, untuk lebih memperjelas lagi, terkait perbedaan dari masing-masing istilah, diambil keterangan juga dalam Alquran. Hal ini disandarkan pada pandangan Muhammad Amir dalam tulisannya yang menguraikan beberapa pendekatan dan metode yang berbasis Alquran. Dalam keterangannya, perbedaan masing-masing istilah ini dapat dilihat pada pendekatan emosional $^{72}$. Pasalnya pada tataran paktisnya, pendekatan emosional ini dapat memakai atau menerapkan berbagai metode seperti; metode cerita atau kisah, metode sosio-drama, dan metode cermah. Interpretasi yang diberikan oleh Amir ini, memperjelas bahwa adanya perbedaan antara pendekatan dan metode. Terlihat juga bahwa pendekatan dapat dipastikan sebagai pola yang lebih umum daripada metode. ${ }^{73}$ Berikut ayat Alquran yang memuat pendekatan emosional, yaitu:

${ }^{71}$ Nurhidayati, "Metode Pembelajaran Interaktif," disampaikan pada "Seminar Metode Pembelajaran" bekerja sama dengan mahasiswa KKN-PPL UNY tahun 2011 di SMP N 2 Depok 1.

72 Pendekatan emodional adalah salah satu pendekatan yang telah dijelaskan di atas, yaitu pada bab pengertian pendekatan pembelajaran.

${ }^{73}$ Muhamamd Amir, Perspektig Alquran tentang Metode Pendidikan, Al-Fikr 16, No. 1 (2012), lihat stainwatampone.ac.id/buku/MetodePendidikan-dalam-Al-Quran.pdf (diases pada tanggal 24 Oktober 2018) 
|Reksiana

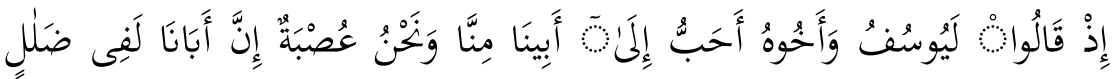
مُبِينِ

Artinya : “(Yaitu) ketika mereka berkata: "Sesungguhnya Yusuf dan saudara kandungnya (Bunyamin) lebih dicintai oleh ayah kita dari pada kita sendiri, padahal kita (ini) adalah satu golongan (yang kuat). Sesungguhnya ayah kita adalah dalam kekeliruan yang nyata." (Yusuf [12]:8).

Dalam keterangan Muhamamd Amir, bahwa ayat di atas merupakan salah satu contoh adanya pendekatan emosional yang digambarkan oleh Alquran.

Dalam ayat lain juga juga diterangkan perihal perbedaan pendekatan dan metode, seperti dalam surat Luqman yang menurut Muhammad Amir juga menerangkan suatu pendekatan yang dibarangi dengan beberapa metode di dalamnya. Berikut surat Luqman yang berbunyi:

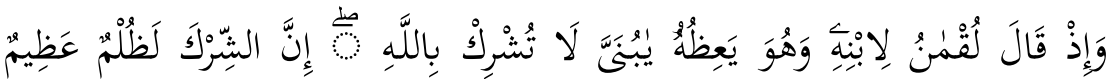
1 1 :1

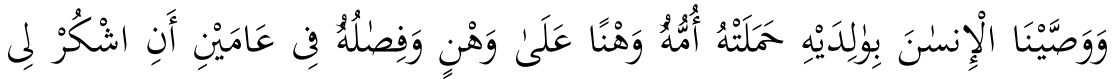

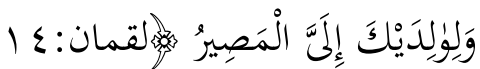

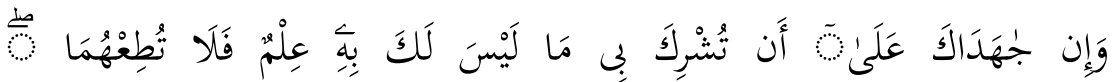

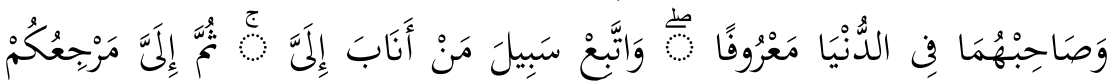

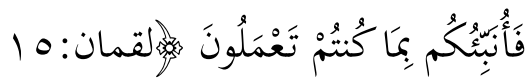

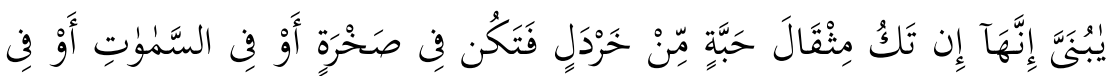

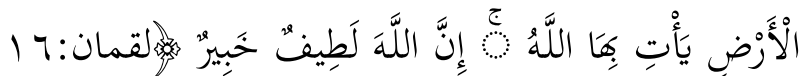

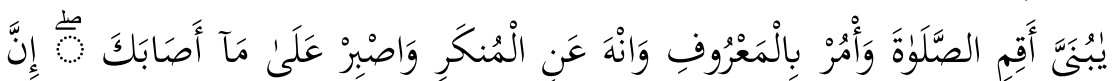

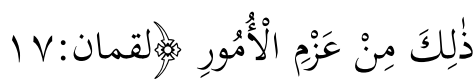

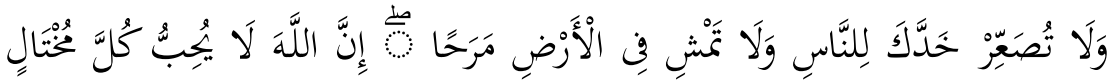
فَخْورِ 
Artinya : "Dan (Ingatlah) ketika Luqman Berkata kepada anaknya, di waktu ia memberi pelajaran kepadanya: "Hai anakku, janganlah kamu mempersekutukan Allah, Sesungguhnya mempersekutukan (Allah) adalah benar-benar kezaliman yang besar". Dan kami perintahkan kepada manusia (berbuat baik) kepada dua orang ibu-bapanya; ibunya Telah mengandungnya dalam keadaan lemah yang bertambah- tambah, dan menyapihnya dalam dua tahun. Bersyukurlah kepadaku dan kepada dua orang ibu bapakmu, Hanya kepada-Kulah kembalimu." ${ }^{, 74}$ (Luqman [31]:13-19).

Intrpretasi dalam surat Luqman ini, menurut Muhammad Amir, bahwa pendekatan seperti ini menjadi penting bagi para anak didik, sehingga pengembangan potensi dirinya selalu seimbang antara pengembangan psikomotorik, apektif dan kognitif. Terlihat dengan jelas bahwa dari penjebaran yang diberikan oleh Muhammad Amir ini, dapat dipahami secara kongkret, bahwa dalam Alquran juga mengisyaratkan adanya berbagai pendekatan dan metode dalam pendidikan Islam. Bahkan, dapat dikatakan Alquran juga turut memberi keterangan terkait perbedaan istilah-sitilah tersebut.

Melihat dari semua argumen, penjelasan dan keterangan di atas oleh beberapa tokoh di atas, dapat diketahui secara nyata dan jelas, adanya perbedaan dalam istilah-sitilah pengajaran seperti: model, pendekatan, strategi, dan metode, serta teknik dan taktik pembelajaran. Perbedaan-perbedaan ini mengacu pada orientasi definisi, pemaknaan, serta pada tahap implementasi dari masingmasing istilah tersebut. Jika dianalisis pada makna dan definisi dari masing-masing istilah, akan ditemukan pengertian model pembelajaran dimaknai sebagai pola dasar dan umum yang diambil dari sebuah teori belajara tertentu.

Hal ini disandarkan pada argumen Endang Mulyatiningsih dan Nurhidayati yang memaknai model pembelajaran sebagai

${ }^{74}$ Muhamamd Amir, Perspektig Alquran tentang Metode Pendidikan, Al-Fikr 16, No. 1 (2012), lihat stainwatampone.ac.id/buku/MetodePendidikan-dalam-Al-Quran.pdf (diases pada tanggal 24 Oktober 2018) 


\section{|Rekssiana}

pola paling umum atau masih bersifat konseptual. Siti Alimah, dan Aditya Marianti, juga memberikan keterangan yang sama, bahwa dalam model pembelajaran sudah mencerminkan penerapan suatu pendekatan, metode, teknik atau taktik pembelajaran sekaligus. Bahkan menurut Rusman, model pembelajaran adalah suatu rencana atau pola yang dapat digunakan untuk membentuk kurikulum, merancang bahan-bahan pembelajaran dan membimbing pembelajaran di kelas. Terkait makna pendekatan, dapat merujuk kepada artian di mana terjadinya suatu proses pembelajaran yang sifatnya masih sangat luas atau global. Tokoh seperti Rusman, Endang Mulyatiningsih dan lain-lain membagi dua jenis pendekatan dalam pembelajaran yaitu 1) pendekatan yang berpusat pada guru (teacher centered approach), dan 2) pendekatan yang berpusat pada siswa (student centered approach). Berlanjut pada pemakanaan tentang strategi yang diartikan Fanani, Rusman, Nurhidayati dan Wina Sanjaya, sebagai suatu sistem yang di dalamnya dapat aplikasikan oleh beberapa metode atau bersifat konseptual. Dan terakhir, pada makna metode, teknik dan taktik pembelajaran. Pemaknaan metode disepakati secara umum adalah suatu cara yang digunakan oleh guru untuk mencapai target pembelajaran. Berlanjut pada tataran praktiknya, guru dapat menggunakan teknik dan taktik tertentu pada implementasi metode pembelajaran.

\section{G. Penutup}

Setalah mengemukakan dan menganalisis beberapa pendapat dari masing-masing tokoh di atas, maka penulis dapat menyimpulkan bahwa, masing-masing istilah seperti: model, pendekatan, strategi, metode, teknik dan taktik pembelajaran memiliki perbedaan yang nyata, baik dari aspek pengertian, pemaknaan kata, bahkan pada tahap implementasinya. Jika melihat dari perbedaan makna, yang telah penulis jabarkan di atas, maka akan terlihat bahwa model pembelajaran menjadi pola dasar paling umum, yang dapat menaungi pendekatan, strategi, metode, teknik dan taktik. Kemudian, pada tahap implementasinya maka akan mengacu pada bagan yang penulis gambarkan bi bawah ini: 


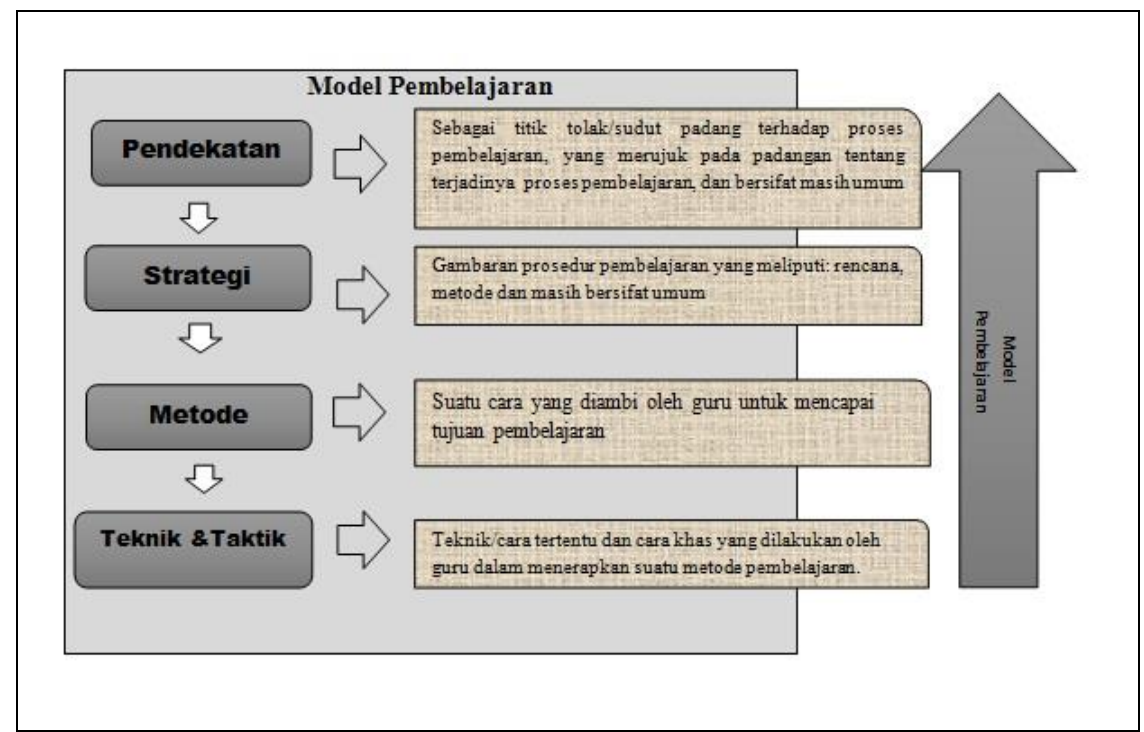

\section{Daftar Pustaka}

Alimah, Siti dan Aditya Marianti. Jelajah Alam Sekitar: Pendekatan, Strategi, Model, dan Metode Pembelajaran Biologi Berkarakter untuk Konservasi. Semarang: FMIPA Universitas Negeri Semarang, 2016.

Arif, Armai. Inovasi Pembelajaran PAI. Jakarta: UIN Press 2017. Fathurrohman, Pupuh. Strategi Belajar Mengajar. Bandung: PT Refika Aditama, 2014.

Fathurroman, Muhammad. Model-model Pembelajaran Inovatif. Yogjakarta: Ar-Ruzz Media, 2016.

Hamalik, Oemar. Kurikulum dalam Pembelajaran. Jakarta: Bumi Aksara, 2009.

Majid, Abdul. Stategi Pembelajara. Bandung: PT Remaja Rodakarya, 2016.

Ramayulis. Metodologi Pendidikan Agama Islam. Jakarta: Kalam Mulia, 2013.

Rusman. Model-model Pembelajaran: Mengembangkan Profesionalisme Guru. Jakarta: PT Raja Grafindo Persada, 2016.

Sanjaya, Wina. Strategi Pembelajaran: Berorientasi Standar Proses Pendidikan. Jakarta: Kencana, 2016

Tim Kurikulum dan Pembelajaran Direktorat Pembelajaran dan Kemahasiswaan, Buku Penduan Kurikulum Pendidikan 
Tinggi. Direktorat Jenderal Pendidikan Tinggi Kementerian

Pendidikan dan Kebudayaan, 2014.

Ardian, Aan dan Sudji Munadi. "Pengaruh Student-Centered

Learning dan Kemampuan Spasial terhadap Kreativitas

Mahasiswa." Jurnal Pendidikan Teknologi dan Kejuruan 22, No. 4 (2015).

Dewika, Pebrina dkk. "Strategi Guru dalam Mengembangkan

Kreativitas Siswa pada Pembelajaran Seni Tari di SMA

Negeri 3 Payakumbuh," E-Jurnal Sendratasik FBS

Universitas Negeri Padang, 2 No. 1 (2013).

Direktorat Tenaga Kependidikan Ditjen PMPTK, Modul Strategi

Pembelajaran (Versi Online).

Fanani, Ahwan. "Mengurangi Kerancuan Istilah Strategi dan

Metode Pembelajaran." Jurnal Pendidikan Islam 8, No. 2 (2014).

Mulayiningsih, Endang. "Pembelajaran PAIKEM" (Depok:

Direktorat Jenderal Peningkatan Mutu Pendidik dan Tenaga

Kependidikan).

Nurhidayati. "Metode Pembelajaran Interaktif." Disampaikan pada "Seminar Metode Pembelajaran" bekerja sama dengan mahasiswa KKN-PPL UNY tahun 2011 di SMP N 2 Depok 1.

Rianie, Nurjannah. "Pendekatan dan Metode Pendidikan Islam:

Sebuah Perbandingan dalam Konsep Teori Pendidikan

Islam dan Barat," Management og Education 1, No 2.

(2014).

Rianto, Milan dkk. Pendekatan, Strategi dan Metode Pembelajaran: Bahan Ajar Diklat Mata Pelajaran Pendidikan Kewarganegaraan SMA Jenjang Dasar. Departemen Pendidikan Nasional Direktorat Jenderal

Peningkatan Mutu Pendidik dan Tenaga Kependidikan Pusat Pengembangan Penataran Guru IPS dan PMP Malang, 2006.

Rochman, Yuli Agustin. "Penerapan Discovery Learning sebagai Mata Kuliah Perencanaan dan Pengendalian Produksi." Badan Pengembangan Akademik Universitas Islam Indonesia: Working Paper Series, (015.

Salafudin. "Metode Pembelajaran Aktif Ala Rasulullah: Pembelajaran yang Membangkitakan Motivasi : (Suatu Metode Pembelajaran dari Hadis)," Forum Tarbiyah 9, No. 2,2011 
Puwanto, Edi. "Analisis terhadap Metode Pendidikan Menurut Alquran dalam Membentuk Karakter Bangsa." Jurnal Pendidikan Agama Islam: Ta'lim13, No. 1 (2015). 